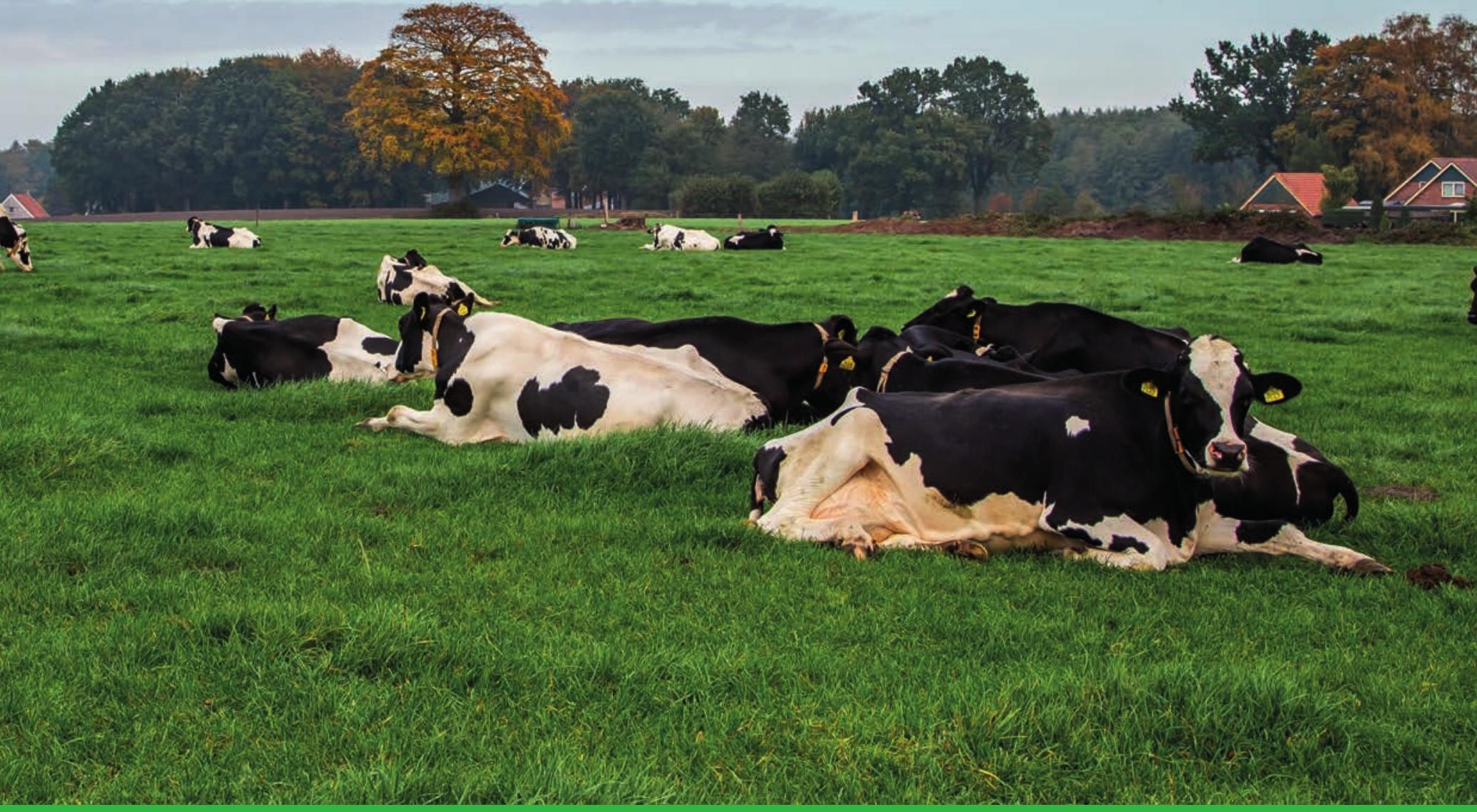

\title{
De potentie voor koolstofvastlegging in Gelderse landbouwbodems
}

Jan Peter Lesschen, Chantal Hendriks, Rima Porre 



\section{De potentie voor koolstofvastlegging in Gelderse landbouwbodems}

Jan Peter Lesschen, Chantal Hendriks, Rima Porre

Dit onderzoek is uitgevoerd door Wageningen Environmental Research en gesubsidieerd door de Provincie Gelderland. Bob Fabri van Eurofins heeft de analyse van beschikbare bodemdata uit de Eurofins database uitgevoerd. Floris Verhagen van Royal HaskoningDHV heeft bijgedragen aan het verzamelen van informatie over relevante bodemprojecten in de provincie Gelderland.

Wageningen Environmental Research

Wageningen, juli 2021

Gereviewd door:

Thalisa Slier, onderzoeker Bodem en klimaat (Wageningen Environmental Research)

Akkoord voor publicatie:

Gert Jan Reinds, teamleider van Duurzaam Bodemgebruik

Rapport 3097

ISSN 1566-7197 
Lesschen, J.P., Hendriks, Porre, R.J., 2021. De potentie voor koolstofvastlegging in Gelderse landbouwbodems. Wageningen, Wageningen Environmental Research, Rapport 3097. 50 blz.; 12 fig.; 4 tab.; 54 ref.

De Provinciale Staten in Gelderland hebben de ambitie vastgesteld om in 2030 de uitstoot van broeikasgassen in Gelderland 55\% lager te laten zijn dan in 1990. Ook koolstofvastlegging in bodem en vegetatie moet hier aan bijdragen. In deze studie is de potentie voor CO2-vastlegging in Gelderse landbouwbodems in kaart gebracht. Het gaat dan om potentie voor verschillende maatregelen en ook waar (regio en grondsoort) deze potentie hebben. Meer blijvend grasland en het toepassen van extra vaste mest hebben de hoogste potentie voor Gelderland, gevolgd door mais in grasland met strokenfrees en het zaaien van een vanggewas/groenbemester na de oogst.

Trefwoorden: bodem, maatregelen, CO2-vastlegging, Gelders Energie Akkoord, broeikasgasemissies

Dit rapport is gratis te downloaden van https://doi.org/10.18174/549171 of op www.wur.nl/environmental-research (ga naar 'Wageningen Environmental Research' in de grijze balk onderaan). Wageningen Environmental Research verstrekt geen gedrukte exemplaren van rapporten.

(C) 2021 Wageningen Environmental Research (instituut binnen de rechtspersoon Stichting Wageningen Research), Postbus 47, 6700 AA Wageningen, T 03174807 00, www.wur.nl/environmental-research. Wageningen Environmental Research is onderdeel van Wageningen University \& Research.

- Overname, verveelvoudiging of openbaarmaking van deze uitgave is toegestaan mits met duidelijke bronvermelding.

- Overname, verveelvoudiging of openbaarmaking is niet toegestaan voor commerciële doeleinden en/of geldelijk gewin.

- Overname, verveelvoudiging of openbaarmaking is niet toegestaan voor die gedeelten van deze uitgave waarvan duidelijk is dat de auteursrechten liggen bij derden en/of zijn voorbehouden.

Wageningen Environmental Research aanvaardt geen aansprakelijkheid voor eventuele schade voortvloeiend uit het gebruik van de resultaten van dit onderzoek of de toepassing van de adviezen.

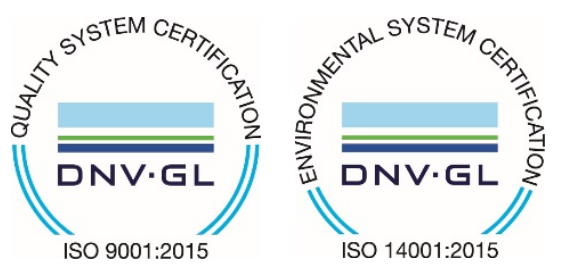

Wageningen Environmental Research werkt sinds 2003 met een ISO 9001 gecertificeerd kwaliteitsmanagementsysteem. In 2006 heeft Wageningen Environmental Research een milieuzorgsysteem geïmplementeerd, gecertificeerd volgens de norm ISO 14001.

Wageningen Environmental Research geeft via ISO 26000 invulling aan haar maatschappelijke verantwoordelijkheid.

Wageningen Environmental Research Rapport 3097 | ISSN 1566-7197

Foto omslag: Shutterstock 


\section{Inhoud}

Verantwoording $\quad 5$

$\begin{array}{ll}\text { Samenvatting } & 7\end{array}$

1

$\begin{array}{ll}\text { Introductie } & 9\end{array}$

1.1 Achtergrond $\quad 9$

$\begin{array}{lll}1.2 & \text { Doel } & 9\end{array}$

1.3 Aanpak en afbakening 9

$\begin{array}{ll}\text { Huidige koolstofvoorraad } & 11\end{array}$

2.1 Landgebruik en bodem 11

2.2 Bodemorganischestof- en koolstofgehalten 11

$\begin{array}{lll}2.3 & \text { Trend in organischestofgehalte } & 13\end{array}$

3

$\begin{array}{ll}\text { Methodologie } & 15\end{array}$

$\begin{array}{lll}3.1 & \text { Aanpak } & 15\end{array}$

3.2 Modelbeschrijving $\quad 15$

$\begin{array}{lll}3.3 & \text { Invoergegevens } & 16\end{array}$

$4 \quad$ Beschrijving en kwantificering van bodem C-maatregelen $\quad 17$

$\begin{array}{lll}4.1 & \text { Verbeteren gewasrotatie } & 17\end{array}$

$\begin{array}{lll}4.2 & \text { Blijvend grasland } & 17\end{array}$

$\begin{array}{lll}4.3 & \text { Aanvoer externe organische stof } & 18\end{array}$

$\begin{array}{lll}4.3 .1 & \text { Vaste mest } & 18\end{array}$

4.3.2 Compost en bokashi 18

4.4 Vanggewassen/groenbemesters $\quad 19$

$\begin{array}{lll}4.5 & \text { Gewasresten achterlaten } & 20\end{array}$

$\begin{array}{lll}4.6 & \text { Snijmais met strokenfrees } & 21\end{array}$

$\begin{array}{lll}4.7 & \text { Verhogen gewasproductie } & 21\end{array}$

$\begin{array}{lll}4.8 & \text { Akkerranden } & 21\end{array}$

4.9 Vogelakkers $\quad 22$

4.10 Niet-gemodelleerde maatregelen $\quad 22$

4.10.1 Niet-kerende grondbewerking $\quad 22$

4.10.2 Kruidenrijk grasland $\quad 22$

4.10.3Diep wortelende gewassen $\quad 23$

$\begin{array}{ll}\text { 4.10.4Agroforestry } & 23\end{array}$

$\begin{array}{ll}\text { 4.10.5Landschapselementen } & 23\end{array}$

$5 \quad$ Resultaten en discussie $r 25$

$\begin{array}{lll}5.1 & \text { Huidige bodemkoolstofbalans } & 25\end{array}$

5.2 Potentie C-vastleggingsmaatregelen $\quad 26$

$\begin{array}{ll}5.3 & \text { Discussie en aanbevelingen }\end{array}$

$6 \quad$ Relevante projecten bodem C Gelderland $\quad 32$

$\begin{array}{ll}\text { Literatuur } & 35\end{array}$

$\begin{array}{llr}\text { Bijlage } 1 & \text { Beschrijving projecten } & 38\end{array}$ 



\section{Verantwoording}

Rapport: 3097

Projectnummer: 5200046678

Wageningen Environmental Research (WENR) hecht grote waarde aan de kwaliteit van zijn eindproducten. Een review van de rapporten op wetenschappelijke kwaliteit door een referent maakt standaard onderdeel uit van ons kwaliteitsbeleid.

Akkoord Referent die het rapport heeft beoordeeld,

functie: $\quad$ Onderzoeker Bodem en klimaat

naam: Thalisa Slier

datum: 14-6-2021

Akkoord teamleider voor de inhoud,

naam: Gert Jan Reinds

datum: 15-6-2021 


\section{Samenvatting}

De Provinciale Staten in Gelderland hebben de ambitie vastgesteld om in 2030 de uitstoot van broeikasgassen in Gelderland 55\% lager te laten zijn dan in 1990. Ook koolstofvastlegging in bodem en vegetatie moet hieraan bijdragen. $\mathrm{Er}$ is behoefte aan beter inzicht in de potentie voor koolstofvastlegging in Gelderse landbouwbodems. Deze studie maakt gebruik van beschikbare data en kennis op het gebied van koolstofvastlegging in landbouwbodems, o.a. uit het LNV programma Slim Landgebruik, en maakt deze specifiek voor de provincie Gelderland. Voor de berekening van potentiële $\mathrm{C}$-vastlegging in landbouwbodems wordt aangesloten bij berekeningen die gedaan zijn op nationale schaal (Lesschen et al., in press).

Landgebruik is samen met grondsoort en grondwaterstand de bepalendste factor voor bodemkoolstof. Meer dan de helft van het areaal van de provincie Gelderland bestaat uit landbouwgrond (55\%), waarvan grasland met $41 \%$ het grootste deel uitmaakt. Voor het bepalen van de huidige bodem organischestof- en koolstofgehalten in Gelderland, is gebruikgemaakt van twee verschillende datasets. De eerste dataset is de nationale CC-NL-dataset, waarbij in 2018 op 1152 locaties in Nederland bodems bemonsterd zijn, waarvan 142 in Gelderland. De andere dataset is gebaseerd op bodemanalyses voor bemestingsadvies die in opdracht van boeren door Eurofins zijn uitgevoerd. Het aantal beschikbare bodemanalyses voor Gelderland ligt gemiddeld rond de 14.000 per jaar, maar varieert van 7.000 tot 19.000 per jaar.

Voor het berekenen van de potentiële C-vastlegging in Gelderse landbouwbodems is gebruikgemaakt van de resultaten uit Lesschen et al. (in press), waarbij een reeks van maatregelen die koolstofvastlegging bevorderen, zijn doorgerekend op nationale schaal. Hierbij is gebruikgemaakt van het bodem C-model RothC, een dynamisch model dat de koolstofdynamiek in minerale bodems kan simuleren. Het model houdt rekening met de effecten van bodemtype, temperatuur, vochtgehalte en bodembedekking op de afbraak van organische koolstof. Voor toepassing op regionale schaal is het model ingebouwd in het MITERRA-NL model. RothC wordt gebruikt om op viercijferig postcodeniveau per gewas de koolstofbalans te bereken op basis van gegevens over bemesting, gewasopbrengst en bodemgegevens. Het basisjaar waarvoor de berekeningen zijn uitgevoerd, is 2017 (de baseline), de maatregelen zijn daarna apart doorgerekend en worden vergeleken met de baseline.

Voor Gelderland zijn meer blijvend grasland, extra vaste mest, snijmais met strokenfrees en vanggewassen/groenbemesters de maatregelen met de meeste potentie voor C-vastlegging. Dit zijn allemaal maatregelen die met name toepasbaar zijn in de melkveehouderij. In de meeste Gelderse regio's is een gemiddelde vastlegging van 400-600 kg CO$/$ ha landbouwgrond mogelijk. In het zuiden van de provincie is het potentieel iets hoger, terwijl rond de Veluwe en in het westen van de Betuwe de potentie lager ligt. De berekende potentie voor $\mathrm{CO}_{2}$-vastlegging in Gelderse landbouwbodems is in totaal ongeveer $86 \mathrm{kton} \mathrm{CO}_{2}$ per jaar. Dit is ongeveer $3 \%$ van de totale broeikasgasemissie uit de Gelderse landbouw (excl. glastuinbouw). In dat opzicht is de potentiële vastlegging niet heel veel, maar zoals voor alle klimaatmitigatie maatregelen geldt, is er niet één maatregel met een heel grote potentie.

Naast $\mathrm{CO}_{2}$-vastlegging in bodems zijn er ook nog mogelijkheden voor $\mathrm{CO}_{2}$-vastlegging in biomassa. Binnen de landbouw zou dit kunnen in agroforestry-systemen en in landschapselementen zoals houtwallen. Als het areaal landschapselementen wordt uitgebreid naar 1 of $2 \%$ van het landbouwareaal, kan 45 tot $106 \mathrm{kton} \mathrm{CO}_{2} /$ jaar extra worden vastgelegd. Dit is in dezelfde ordegrootte als de potentie in bodems, maar bij landschapselementen gaat het wel deels ten koste van landbouwgrond. De maatregelen die C-vastlegging in de bodem bevorderen, hebben daarnaast ook positieve effecten op bodemkwaliteit, dragen bij aan klimaatadaptatie en kunnen lachgasemissie en nitraatuitspoeling verlagen. 


\section{$1 \quad$ Introductie}

\subsection{Achtergrond}

De Provinciale Staten in Gelderland hebben de ambitie vastgesteld om in 2030 de uitstoot van broeikasgassen in Gelderland terug te dringen met 55\% vergeleken met 1990 en in 2050 klimaatneutraal te zijn.

In het Gelders Energieakkoord (GEA) werken meer dan honderd organisaties op lokaal, regionaal en provinciaal niveau samen op het gebied van duurzame energieopwekking, energiebesparing, scholing en innovatie om deze ambitie waar te gaan maken. GEA heeft ook een programma landbouw en grondgebruik opgesteld, dat als doel heeft om bij te dragen aan deze reductiedoelstelling binnen drie sporen:

1. Verminderen van de $\mathrm{CO}_{2}$-uitstoot in de land- en tuinbouwsector door verlaging van het energieverbruik $\left(0,36\right.$ Mton $\left.\mathrm{CO}_{2}\right)$,

2. Terugdringen van dier-gerelateerde broeikasgasemissies op bedrijfsniveau $\left(0,75 \mathrm{Mton} \mathrm{CO}_{2}\right.$-eq) en

3. Vastleggen van $\mathrm{CO}_{2}$ in bodem en vegetatie $\left(0,2-0,3 \mathrm{Mton} \mathrm{CO}_{2}\right.$, waarvan 0,05 tot 0,075 $\mathrm{Mt} \mathrm{CO}_{2}$ in landbouwbodems en 0,1 tot $0,2 \mathrm{Mt} \mathrm{CO}_{2}$ in bomen, bossen en natuur).

Onder dit programma is ook een werkgroep Bodem actief, met vertegenwoordigers vanuit o.a. LTO, het waterschap, de provincie, de gemeenten en grondeigenaren. Hierbij wordt integraal gekeken naar beter bodembeheer, omdat dit naast koolstofvastlegging kan bijdragen aan andere bodemfuncties, zoals waterbeheer (betere infiltratie en vasthouden van water), bodemvruchtbaarheid en biodiversiteit en een goede economische positie voor de boer.

In eerdere studies heeft Wageningen Environmental Research (WENR) de emissies uit de landbouwsector berekend voor de provincie Gelderland. Zo heeft er een studie plaatsgevonden waarin een nulmeting is uitgevoerd voor het jaar 2005 (Lesschen et al., 2009) en een studie waarin een update van de broeikasgasemissiecijfers van deze nulmeting is uitgevoerd voor peiljaar 2016 (Jeurissen et al., 2019). Uit deze studies blijkt dat de Gelderse land- en tuinbouwsector voor 5,4\% bijdraagt aan de Gelderse broeikasgasuitstoot, waarvan een groot deel als methaan $\left(\mathrm{CH}_{4}\right)$ en lachgas $\left(\mathrm{N}_{2} \mathrm{O}\right)$ uitgestoten wordt. In deze voorgaande studies zijn $\mathrm{CO}_{2}$-emissie en -vastlegging in bodems niet meegenomen. Aangezien de provincie en de GEA-werkgroep willen inzetten op het vastleggen van $\mathrm{CO}_{2}$ in bodem en vegetatie, is er behoefte aan een beter inzicht in de potentie voor C-vastlegging in Gelderse landbouwbodems.

\subsection{Doel}

Dit project heeft als doel om inzicht te geven in de potentie voor koolstofvastlegging in minerale landbouwbodems in de provincie Gelderland. Het gaat dan om potentie voor verschillende maatregelen en ook waar (regio en grondsoort) deze potentie hebben.

\subsection{Aanpak en afbakening}

Deze studie maakt gebruik van beschikbare data en kennis op het gebied van C-vastlegging in landbouwbodems, o.a. uit het klimaatenvelop programma Slim Landgebruik ${ }^{1}$, en maakt deze specifiek voor de provincie Gelderland. Voor de berekening van potentiële C-vastlegging in landbouwbodems wordt aangesloten bij berekeningen die gedaan worden op nationale schaal (Lesschen et al., in press).

${ }^{1}$ https://www.slimlandgebruik.nl/ 
Koolstofvastlegging in bodems onder bos en natuur wordt niet meegenomen in deze studie. Effecten van bodem C-vastlegging op andere emissies of gewasgroei worden ook niet expliciet meegenomen, maar er wordt wel een kwalitatieve inschatting gegeven van mogelijke afwentelingseffecten.

\section{Omrekening organische stof, koolstof en $\mathrm{CO}_{2}$}

In dit rapport worden de termen organische stof, koolstof en $\mathrm{CO}_{2}$ gebruikt. In dit tekstkader wordt kort uitgelegd hoe deze termen zich tot elkaar verhouden.

- Bodemorganische stof is het organische materiaal in de bodem. Deze organische stof bestaat voor ongeveer $50 \%$ uit koolstof $(C)$, echter met behoorlijke variatie (30-70\%), die afhangt van de bodem en de oorsprong van het organische materiaal.

- Het RothC-model rekent met koolstofvoorraden en niet met organischestofgehalten. Voor de invoerdata is dan ook het C-gehalte in de bodem gebruikt en niet het OS-gehalte.

- Voor de impact op het klimaat wordt de koolstofvastlegging omgerekend naar $\mathrm{CO}_{2}$; hiervoor wordt de factor $44 / 12$ (molmassa $\mathrm{CO}_{2} / \mathrm{C}$ ) gebruikt. Dus 1 ton $\mathrm{C}$ is 3,67 ton $\mathrm{CO}_{2}$.

In dit rapport wordt in hoofdstuk 2 eerst een overzicht gegeven van de huidige organischestofgehalten in de Gelderse landbouwbodems en de trend. Hiervoor wordt gebruikgemaakt van een recente nationale dataset (CC-NL) en van praktijkdata uit de Eurofins-database. In hoofdstuk 3 worden de toegepaste methode en het gebruikte model beschreven. Vervolgens worden in hoofdstuk 4 de verschillende maatregelen die koolstofvastlegging bevorderen beschreven en de manier waarop ze in het model gekwantificeerd zijn. De resultaten en discussie hiervan staan in hoofdstuk 5 . Ten slotte wordt in hoofdstuk 6 nog een overzicht gepresenteerd van relevante lopende of recentelijk afgesloten projecten voor bodemkoolstofvastlegging. Dit overzicht kan helpen bij het opstarten van nieuwe projecten en initiatieven die bodem C-vastlegging willen stimuleren. 


\section{$2 \quad$ Huidige koolstofvoorraad}

\subsection{Landgebruik en bodem}

Landgebruik is samen met grondsoort en grondwaterstand de bepalendste factor voor bodemkoolstof. Landbouwgrond in Gelderland beslaat meer dan de helft van het areaal (55\%), waarbij grasland met $41 \%$ het belangrijkst is en akkerland met $14 \%$ veel minder areaal beslaat. Het grootste deel van het akkerland bestaat uit snijmais voor de melkveehouderij. Naast landbouw heeft Gelderland ook grote arealen natuur, met ruim $23 \%$ van het land onder natuurlijke vegetatie, zoals bos en heide. Daarnaast is nog $17 \%$ van het land bebouwd gebied. Gelderland bestaat voor ongeveer de helft uit zandgronden en voor $30 \%$ uit kleigronden. De zandgronden beslaan voornamelijk het oosten van Gelderland en de Veluweregio, de kleigronden de gebieden rondom de grote rivieren (Figuur 1). Een klein deel van de zandgronden zijn eerdgronden. Dat zijn bodems met een humusrijke bovengrond die zijn ontstaan door het eeuwenlang opbrengen van humushoudende plaggen door de mens. Slechts een klein deel van de Gelderse bodems zijn organische gronden (veen en moerige gronden); deze zijn gelegen boven Elburg en bij Nijkerk.

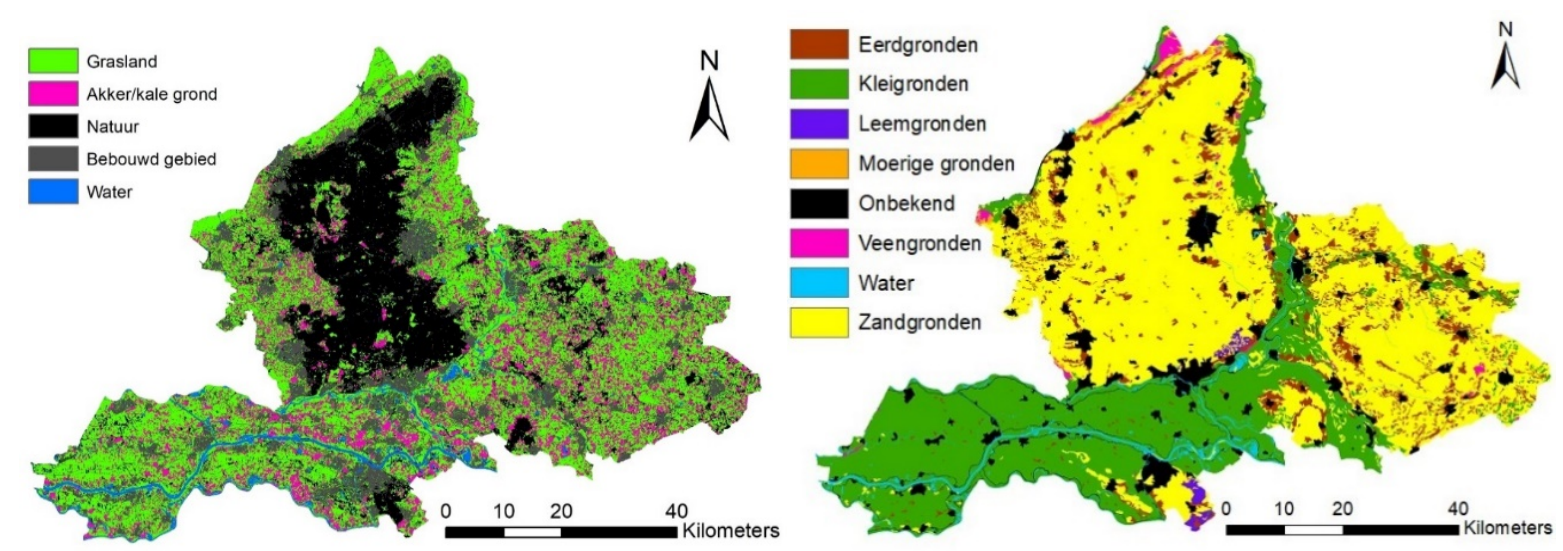

Figuur 1 Landgebruik in Gelderland (links) met als hoofdklassen grasland en akkerland, gebaseerd op de Basiskaart natuur 2017 en een bodemkaart met hoofdbodemgroepen (rechts).

Het akkerland ligt voor $40 \%$ op zandgrond en voor $45 \%$ op kleigrond, terwijl grasland respectievelijk $43 \%$ en $40 \%$ beslaat. Naast gras en snijmais voor de (melk)veehouderij, zijn wintertarwe, consumptieaardappelen, kwekerijen en suikerbieten de meest voorkomende gewassen in Gelderland. Fruitbomen hebben ook een aanzienlijk aandeel op de zavelgronden rondom en tussen de rivieren. Het aandeel groenbemesters is met 6,4\% van het totale areaal groenbemesters in Nederland relatief laag in Gelderland. Dit komt deels door het grote areaal grasland. Bladrammenas, Italiaans raaigras en Gele Mosterd zijn de meest voorkomende groenbemesters in Gelderland. Dit zijn tevens ook de meest voorkomende groenbemesters in Nederland.

\subsection{Bodemorganischestof- en koolstofgehalten}

Voor het bepalen van de bodemorganischestof- en koolstofgehalten in Gelderland, hebben we gebruikgemaakt van twee verschillende datasets. De eerste dataset is de nationale CC-NL-dataset, waarbij in 2018 op 1152 locaties in Nederland bodems bemonsterd zijn voor de laag 0-30 cm en 30-100 cm (Van Tol-Leenders et al., 2019). Deze meetcampagne is een herbemonstering van de Landelijke Steekproef Kaarteenheden uit de periode 1995-2002. Het voordeel van deze dataset is dat dit een gestratificeerde steekproef is, waarbij voor de combinatie van bodemtype en grondwatertrap 
onafhankelijk locaties geloot zijn. Op deze locaties is de bodem op een uniforme wijze bemonsterd en geanalyseerd. Het organischestofgehalte is bepaald via de standaardmethode van gloeiverlies (loss on ignition) en het organischekoolstofgehalte via de C-elementair-methode. Van de CC-NL-dataset liggen 142 punten in Gelderland, waarvan 98 punten zijn gemeten onder gras- en akkerland.

De andere dataset die is toegepast voor het bepalen van de organischestof- en koolstofgehalten is gebaseerd op bodemanalyses voor bemestingsadvies die in opdracht van boeren door Eurofins zijn uitgevoerd. Eurofins Agro is het grootste bodemlaboratorium in Nederland met zo'n

100.000 bodemmonsters per jaar. De meeste bodemmonsters worden tegenwoordig geanalyseerd via spectroscopie, waarbij uit het Near Infrared signaal de bodemeigenschappen, zoals OS- en C-gehalte kunnen worden afgeleid. Het voordeel van deze dataset is het grote aantal monsters dat beschikbaar is, zowel in tijd als in ruimte. Deze dataset is echter wel afhankelijk van het aantal boeren dat een bemestingsadvies aanvraagt en is daarmee geen onafhankelijke steekproef, zoals CC-NL. Een ander nadeel is dat er voor grasland en akkerland een verschillende meetdiepte wordt gebruikt. Voor grasland is dit $0-10 \mathrm{~cm}$ en voor akkerland $0-25 \mathrm{~cm}$, waardoor percelen met wisselend landgebruik moeilijk te vergelijken zijn. Het aantal beschikbare bodemanalyses voor Gelderland dat voor deze studie is meegenomen, ligt gemiddeld rond de 14.000 per jaar, maar varieert van 7.000 tot 19.000 per jaar.

Op basis van de CC-NL-dataset is het organischestof(OS-)gehalte in de bovengrond het hoogst op kleigronden onder grasland $(6,5 \%$, met een standaardafwijking van $2,8 \%)$ en het laagst op zandgronden onder akkerland (3,5\%, met een standaardafwijking van 0,9\%), zie Tabel 1 . Eurofins heeft tussen 2016 en 2020 voor 69.670 bodemmonsters het OS-gehalte bepaald in Gelderland. Ook uit deze database blijkt dat kleigronden onder grasland het hoogste OS-gehalte hebben $(9,6 \%$, met een standaardafwijking van 2,5\%) en zandgronden onder akkerland het laagste $(4,2 \%$, met een standaardafwijking van 0,6\%). Het hogere OS-gehalte onder grasland wordt veroorzaakt doordat in de Eurofins-dataset alleen de bovenste $10 \mathrm{~cm}$ is bemonsterd, waar het organischestofgehalte hoger is. Hierdoor zijn deze data voor grasland niet direct te vergelijken met de data uit de CC-NL-database.

Tabel 1 Gemiddelde OS- en C-gehalten (in \%, standaardafwijking tussen haakjes) voor Gelderland uit de CC-NL-database $(0-30 \mathrm{~cm}$, gemeten in 2018) en de Eurofins database $(0-10 \mathrm{~cm}$ voor grasland en 0-25cm voor akkerland, gemeten tussen 2016 en 2020).

\begin{tabular}{|c|c|c|c|c|c|c|c|}
\hline & & \multicolumn{3}{|c|}{ CC-NL-database } & \multicolumn{3}{|c|}{ Eurofins-database } \\
\hline Grasland & Zand & 43 & $4,2(1,5)$ & $2,1(0,7)$ & 32905 & $5,6(0,9)$ & $3,0(0,5)$ \\
\hline Akkerland & Klei & 6 & $4,7(3,3)$ & $2,4(1,7)$ & 8217 & $4,8(1,3)$ & $2,3(0,7)$ \\
\hline
\end{tabular}

Hoe het OS-gehalte in gras- en akkerland zich verhoudt t.o.v. andere minerale bodems in Nederland, is weergegeven in Figuur 2. Ten opzichte van de rest van Nederland is het OS-gehalte in de bovengrond van grasland op zand iets lager in Gelderland. Daarentegen is het OS-gehalte in de boven- en ondergrond van akkerland op klei weer iets hoger. De figuur laat echter ook zien dat de spreiding erg groot is, met name voor de bovengrond. 

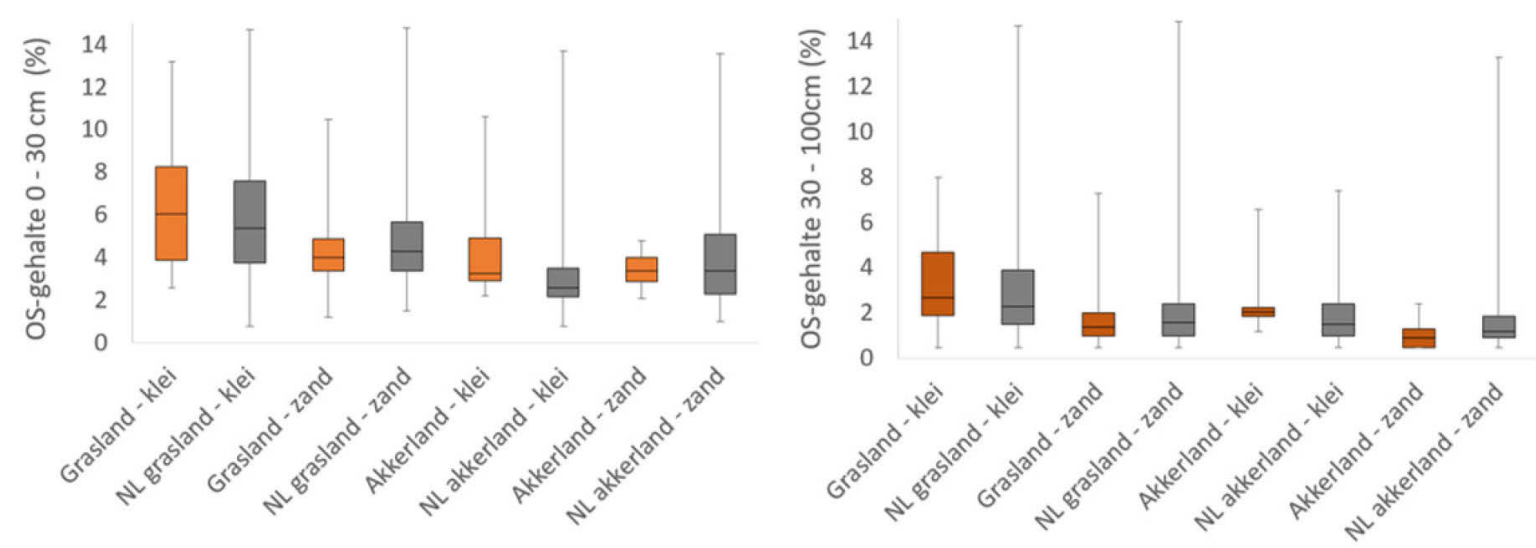

Figuur 2 Het organischestofgehalte in Gelderland (oranje) en Nederland (grijs) voor de bovengrond $(0-30 \mathrm{~cm})(A)$ en de ondergrond $(30-100 \mathrm{~cm})(B)$ uitgesplitst naar landgebruik en grondsoort. Deze data zijn gebaseerd op de CC-NL-dataset (Tol-Leenders et al., 2019). Deze boxplotgrafiek geeft met de 'box' het eerste kwartiel, mediaan en derde kwartiel van alle metingen weer.

Op basis van de Eurofins-dataset is ook de ruimtelijke spreiding van het OS-gehalte onder grasland en akkerland weergegeven op viercijferig postcodeniveau (Figuur 3). Rondom de Rijn liggen de gebieden met het hoogste OS-gehalte, dit zijn met name kleigronden. Vooral kleigronden onder grasland hebben een hoog OS-gehalte van meer dan 9\%. De meeste zandgronden in het oosten van Gelderland hebben een OS-gehalte van 5-7\% onder grasland en van 3-5\% onder akkerland.
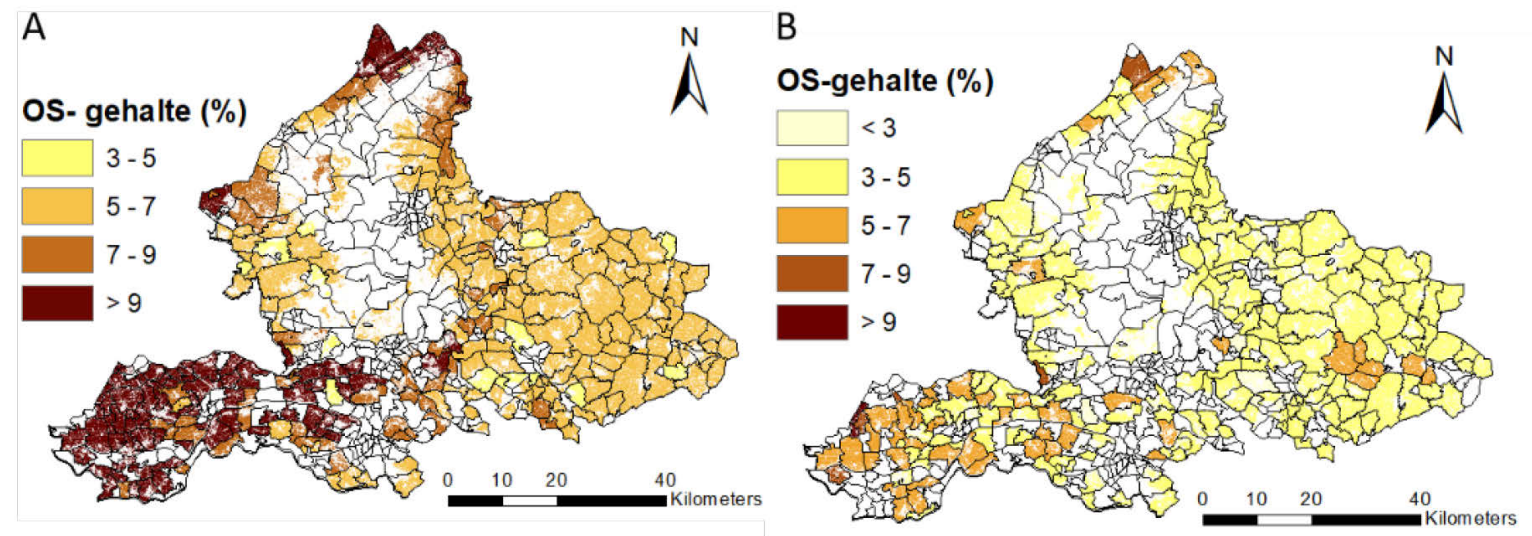

Figuur 3 Het huidige organische stofgehalte in grasland $(A)$ en akkerland $(B)$ gebaseerd op Eurofins data op viercijfer postcode niveau (gemiddelde periode 2016-2020). Alleen postcode gebieden met meer dan 20 metingen zijn in de kaart opgenomen.

\subsection{Trend in organischestofgehalte}

In de Eurofins-dataset zijn ook oudere bodemanalyses van het organischestofgehalte beschikbaar vanaf het jaar 2005. Figuur 4 laat de trend zien voor het gemiddelde OS-gehalte en C-gehalte per jaar voor de minerale landbouwbodems in Gelderland. Het OS-gehalte lijkt een kleine stijging te laten zien voor zowel grasland als bouwland, maar bij het C-gehalte is de trend voor grasland juist negatief. Voor grasland zijn de gemiddelden per jaar ook behoorlijk variabel, met name in het begin van de meetreeks. In die periode zit er ook veel verschil tussen het aantal beschikbare metingen per jaar, wat mogelijk een deel van de variatie kan verklaren. Doordat er elk jaar verschillende percelen zijn bemonsterd, is het niet mogelijk om een statistische uitspraak te doen over de trend in het OSgehalte. De lage $\mathrm{R}^{2}$ van de lineaire regressies laat wel zien dat er geen sprake is van een duidelijke toe- of afname van het OS- en C-gehalte in Gelderse landbouwbodems. 
Trend OS gehalte

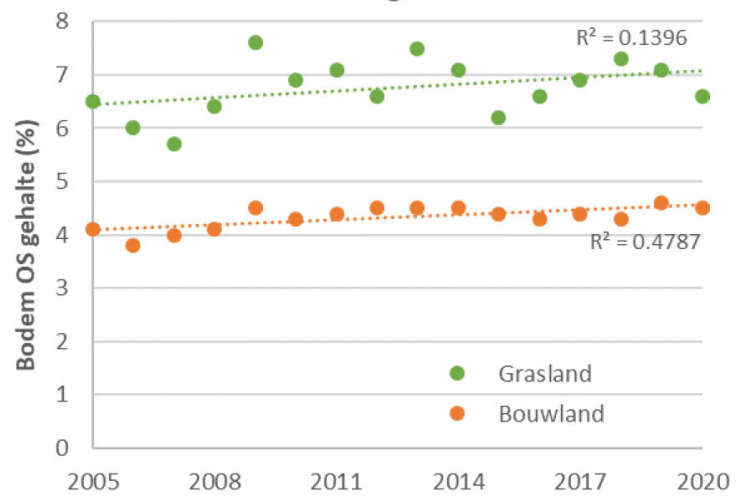

Trend C gehalte

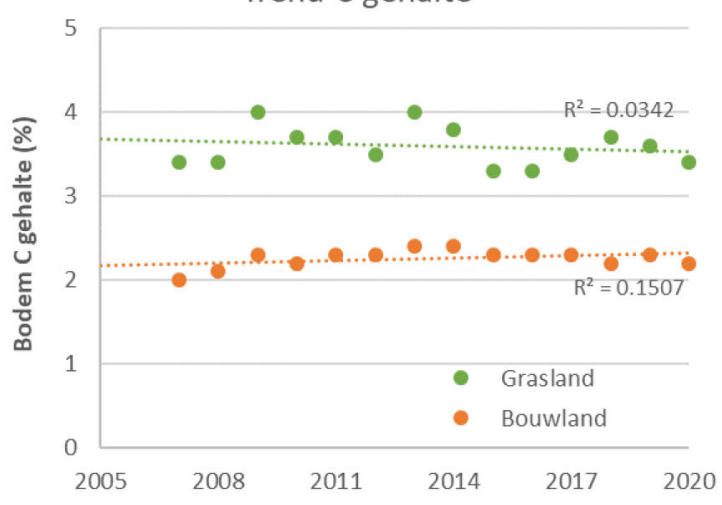

Figuur 4 De trend in het gemiddelde OS-gehalte (links) en C-gehalte (rechts) voor grasland en akkerland op basis van alle Eurofins-bodemanalyses op klei- en zandgrond in de provincie Gelderland.

$\mathrm{Er}$ is ook gekeken naar de ruimtelijk spreiding van de trend in organischestofgehalte. Hiervoor is per driecijferig postcodegebied het gemiddelde OS-gehalte berekend voor de tijdreeks 2006-2010 en 2016-2020. Figuur 5 laat het verschil in OS-gehalte tussen deze twee periodes zien. In de meeste postcodegebieden is geen duidelijke toe- of afname te zien. Voor grasland lijkt het OS-gehalte op de kleigronden in de Betuwe wat te zijn afgenomen, terwijl er in de Gelderse Vallei en het oosten van Gelderland sprake is van een kleine toename. Voor akkerland zijn de verschillen minder groot. Echter ook bij deze kaart is het onduidelijk in hoeverre de verschillen significant zijn, aangezien het geen representatieve steekproef is.
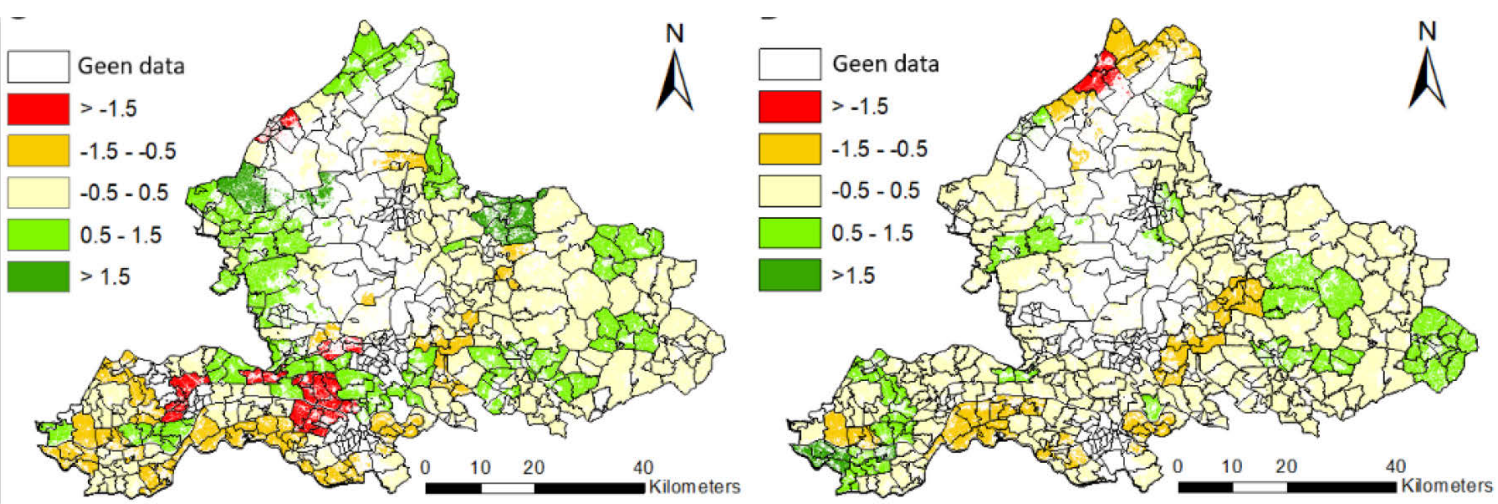

Figuur 5 De toe- of afname in organischestofgehalte (in procentpunten) tussen de periodes 20062010 en 2016-2020 voor grasland (links) en akkerland (rechts) gebaseerd op Eurofins-data op driecijferig postcodeniveau. 


\section{$3 \quad$ Methodologie}

\subsection{Aanpak}

Voor het berekenen van de potentiële C-vastlegging in Gelderse landbouwbodems voor de verschillende bodem C-maatregelen wordt gebruikgemaakt van de resultaten uit Lesschen et al. (in press), waarbij een vergelijkbare studie op nationale schaal is uitgevoerd. Voor die studie is gebruikgemaakt van het bodem C-model RothC om de potentiële C-vastlegging te bepalen. De keuze voor het model is gebaseerd op de wetenschappelijke kwaliteit, toepasbaarheid en benodigde invoergegevens. Het model is goed beschreven in peer-reviewed publicaties (o.a. Coleman et al., 1997; Smith et al., 1997; Byrne en Kiely, 2009), wordt internationaal al veel toegepast en gaat ook gebruikt worden voor de nationale emissieregistratie in Nederland. Het model is daarnaast toepasbaar voor zowel akkerland als grasland en vergt een beperkte set aan invoerdata die ook op regionale schaal beschikbaar is (Lesschen et al., 2020).

Voor toepassing op regionale schaal is het model ingebouwd in het MITERRA-NL model. MITERRA-NL is een emissiemodel voor de Nederlandse landbouw dat rekent op viercijferig postcodeniveau (Lesschen et al., 2011; Conijn en Lesschen, 2015). Op basis van statistische data, o.a. gewasarealen uit Basis Registratie Percelen (BRP), dieraantallen en gewasopbrengst en kunstmestgebruik uit CBS, berekent het model de verdeling van kunstmest en dierlijke mest en de bijbehorende stikstof- en broeikasgasemissies. Het model is vergelijkbaar met het INITIATOR-model, dat gebruikt wordt voor de ruimtelijke verdeling van emissies voor de emissieregistratie en dat eerder is gebruikt voor het berekenen van de landbouwemissies in Gelderland (Jeurissen et al., 2019). Echter, in het INITIATORmodel is nog geen koolstofdynamiek ingebouwd.

RothC wordt gebruikt om op viercijferig postcodeniveau per gewas de koolstofbalans te bereken op basis van gegevens over bemesting, gewasopbrengst en bodemgegevens die uit MITERRA-NL worden afgeleid. Het basisjaar waarvoor de berekeningen zijn uitgevoerd, is 2017 (de baseline), de maatregelen zijn daarna apart doorgerekend en worden vergeleken met de baseline. Deze berekening is uitgevoerd voor één jaar, waarbij de gemiddelde koolstofbalans per viercijferig postcodegebied is berekend voor grasland en akkerland en is omgerekend naar $\mathrm{CO}_{2}$-emissie/-vastlegging. De berekening is gebaseerd op een bodemdiepte van $25 \mathrm{~cm}$. Dit is de laag waarvoor aangenomen wordt dat de meeste aanvoer en afbraak van organische stof plaatsvindt.

\subsection{Modelbeschrijving}

Het RothC-model is een dynamisch model dat de koolstofdynamiek in minerale bodems kan simuleren. Het model is gekalibreerd op langetermijnexperimenten uit Rothamsted (Coleman and Jenkinson, 1996). Het model houdt rekening met de effecten van bodemtype, temperatuur, vochtgehalte en bodembedekking op de afbraak van organische koolstof. In het RothC-model wordt de koolstof verdeeld over vier actieve compartimenten en een deel inerte koolstof. Deze vier actieve compartimenten/pools zijn afbreekbaar plantmateriaal (DPM), resistent plantmateriaal (RPM), microbiële biomassa (BIO) en humus (HUM). Elk van deze pools heeft zijn eigen specifieke afbraakcoëfficiënt (de afbraak is een fractie van de aanwezige hoeveelheid), behalve de inerte organische stof waar geen afbraak meer plaatsvindt. Maandelijkse tijdstappen worden gebruikt om veranderingen in de organische-koolstofvoorraad te berekenen op een tijdschaal van één jaar tot eeuwen. In deze studie is de RothC- versie 26.3 gebruikt zoals beschreven in Coleman en Jenkinson (2014). 


\subsection{Invoergegevens}

Het model heeft de volgende invoergegevens nodig: klimaatgegevens op maandbasis (neerslag, verdamping en gemiddelde luchttemperatuur), het OS-gehalte en kleigehalte van de bodem, de periode van bodembedekking door een gewas, de aanvoer van plantenresten (ton $\mathrm{C} \mathrm{ha}^{-1}$ ), groenbemesters en organische meststoffen naar de bodem (ton $\mathrm{C} \mathrm{ha}^{-1}$ ), en de bodemdiepte waarmee wordt gerekend. Voor de klimaatgegevens hebben we gebruikgemaakt van de dataset gebaseerd op metingen van het KNMI met maandelijkse klimaatdata per KNMI-zone. Voor de bodem Cberekeningen is het weerjaar 2017 gebruikt, dit was qua temperatuur en neerslag het meest gemiddelde jaar van de laatste tien jaar.

Voor bodemdata wordt de 1:50.000 bodemkaart van Nederland ${ }^{2}$ en de C-gehalten uit de CC-NLdataset (Van der Tol et al, 2019) gebruikt. Data over gewasarealen zijn afkomstig van Basisregistratie Percelen (BRP, 2017). Data over de gemiddelde gewasopbrengst van 2016 t/m 2018 zijn afkomstig van het Centraal Bureau voor de Statistiek (CBS). Deze opbrengstcijfers zijn vertaald naar aanvoer van koolstof naar de bodem. Hiervoor is gebruikgemaakt van de zogenaamde 'harvest-index', deze factor geeft aan welk deel van de plant oogstbaar product is. Voor een aantal gewassen, met name granen, is gebruikgemaakt van gewasrestopbrengst-curves van García-Condado et al. (2019). Voor andere gewassen waar geen duidelijke relatie bestaat met de gewasopbrengst (bijv. aardappel en suikerbiet), is gebruikgemaakt van een standaardwaarde gebaseerd op de effectief organische stof (EOS) kengetallen (Wenum et al., 2013).

De huidige afvoer van stro is gebaseerd op data uit het Bedrijven-Informatienet en voor het huidige gebruik van groenbemesters zijn data uit het BRP beschikbaar. Data over de organische stof-input van groenbemesters komt van Koopmans et al. (2020). Deze data bepalen samen met data over het areaal waar groenbemesters gezaaid kunnen worden na de oogst en de fractie waarin dit mogelijk is, de koolstofinput van groenbemesters. Data over de aanvoer van organische mest worden overgenomen uit MITERRA-NL. Het aandeel mest dat verwerkt of geëxporteerd wordt, is afgeleid uit de CBS-statistieken. Bij de Branche Vereniging Organische Reststoffen (BVOR) is bekend hoeveel compost er wordt geproduceerd in Nederland en welk aandeel wordt afgezet binnen de landbouw. Verdere details over de invoerdata en de modelberekeningen staan beschreven in Lesschen et al. (in press).

\footnotetext{
${ }^{2}$ https://www.wur.nl/nl/show/Bodemkaart-1-50-000.htm
} 


\section{Beschrijving en kwantificering van bodem C-maatregelen}

In dit hoofdstuk staan de maatregelen beschreven die kunnen bijdragen aan koolstofvastlegging in minerale landbouwbodems. Elk van de maatregelen wordt kort beschreven en voor elke maatregel wordt aangegeven hoe deze in het model is meegenomen.

\subsection{Verbeteren gewasrotatie}

Intensieve gewassen zoals snijmais, suikerbieten, aardappelen en uien nemen veel nutriënten op uit de bodem en laten weinig gewasresten achter na de oogst. Een rotatie met veel van dit soort intensieve gewassen zorgt dus voor een afname in bodem-organischestof en nutriënten. Als het aandeel rustgewassen (bijv. graangewassen of grassen) verhoogd wordt in de gewasrotatie nemen de organischestof-aanvoer en dus het organischestofgehalte in de bovengrond en de koolstofvastlegging toe (Van Dijk et al., 2012; Koopmans et al., 2019; 2020).

Deze maatregel is gemodelleerd door aan te nemen dat in de akkerbouwrotatie minstens $50 \%$ rustgewassen is opgenomen. Indien dit percentage per viercijferig postcodegebied lager is, wordt het areaal intensieve gewassen (suikerbieten, aardappelen en uien) verlaagd en vervangen door wintertarwe. De keuze voor dit gewas is in lijn met een andere studie (Koopmans et al., 2019). In Gelderland bestaat de gewasrotatie voor de akkerbouw gemiddeld uit 46\% intensieve en 50\% rustgewassen, maar in bepaalde regio's is de rotatie wel intensiever. We nemen aan dat deze maatregel kan worden toegepast voor alle gewassen die in de akkerbouw worden opgenomen. Gras, snijmais, meerjarige gewassen en braakliggend land worden buiten beschouwing gelaten.

\subsection{Blijvend grasland}

De aanvoer van organische stof uit biomassa van gras (zowel boven- als ondergronds) is hoog en de afbraak is relatief laag. Daardoor bouwt het organischestofgehalte in de bodem onder grasland zich op. Dit komt ten goede aan de grasproductie, het bodemleven, maar ook aan het watervasthoudend vermogen. Echter, het scheuren van grasland, bijvoorbeeld voor graslandvernieuwing of de teelt van mais, heeft nadelige gevolgen. Wanneer het grasland gescheurd wordt, komt er veel zuurstof in de bodem en breekt organische stof sneller af. Tevens worden het bodemleven en haar functies verstoord (Van Eekeren et al., 2016) en leidt dit tot een piek in lachgasemissies. Het niet scheuren van grasland kan dus zorgen voor een hogere organischestof-opbouw en een betere bodemstructuur en waterinfiltratie in de bovengrond (Van Eekeren et al., 2008; De Wit et al., 2018).

Deze maatregel is op twee manieren gemodelleerd: 1) optimaal landgebruik volgens de 60-20-20regel voor de melkveehouderij en 2) grondgebonden melkveehouderij met meer grasland. De eerste maatregel is gebaseerd op Van Eekeren et al. (2007), die de 60-20-20-regel voorstelt voor de melkveehouderij met snijmais. Dit betekent dat $60 \%$ van het land uit blijvend grasland bestaat en $20 \%$ uit tijdelijk grasland, liefst met klaver, zodat ook de kunstmestgift kan worden verminderd. Op de overige $20 \%$ wordt snijmaïs geteeld. In een rotatie van drie jaar wisselen tijdelijk grasland en maïs elkaar af. In het model wordt het areaal tijdelijk grasland en snijmais vervangen door blijvend grasland als het areaal boven deze $20 \%$ ligt. Gelderland heeft, vergeleken met andere provincies, een gemiddeld aandeel blijvend grasland met $62 \%$ van het totale areaal grasland en snijmais, en voldoet daarmee al redelijk aan de 60-20-20-regel, maar lokaal kan het aandeel blijvend grasland nog wel worden vergroot.

De tweede maatregel komt voort uit het plan voor een grondgebonden melkveehouderij. Het is de verwachting dat bij de uitvoering van deze maatregel meer eiwit van eigen bedrijf moet komen, 
waardoor er minder snijmais geteeld gaat worden. Op basis van het advies van de Commissie Grondgebondenheid blijkt dat het areaal snijmais in Nederland dan met ongeveer $40 \%$ zou afnemen. Dit betekent dat ook het areaal tijdelijk grasland dat in rotatie is met snijmais kleiner kan worden. Deze maatregel is dan ook doorgerekend met een $40 \%$ kleiner snijmais areaal, een evenredig kleiner tijdelijk graslandareaal dat dan vervangen wordt door blijvend grasland. Dit resulteert voor Gelderland in 25.000 ha extra blijvend grasland.

\subsection{Aanvoer externe organische stof}

\subsubsection{Vaste mest}

In Nederland wordt veel mest geproduceerd, ruim 74,6 miljoen ton in 2019, waarvan het merendeel drijfmest is (Van Bruggen \& Gosseling, 2020). Drijfmest wordt vaak gebruikt in de akkerbouw en melkveehouderij, maar bevat minder organische stof dan vaste mest. Vaste mest wordt gekenmerkt als een vorm van steekbare (vaste) mest. Aan de mest is vaak een variabele hoeveelheid strooisel toegevoegd (De Wit et al., 2020). Naast deze traditionele vaste mest zijn er tegenwoordig ook producten van mestscheiding, waarbij de organische stof met name in de dikke fractie zit. De samenstelling van deze dikke fracties hangt af van de manier van mestscheiding en verwerking. De afgelopen tijd ontstaan er steeds meer geluiden om stalsystemen aan te passen, zodat er geen drijfmest meer wordt geproduceerd, maar waarbij de dunne fractie (urine) en dikke fractie (feces) apart opgevangen worden. Dit leidt ook tot minder ammoniak- en methaanemissies, maar kan ook leiden tot efficiënter gebruik van mest in de landbouw en behoud van organische stof, dat anders deels geëxporteerd wordt.

Voor toepassing van deze maatregel is aangenomen dat door nieuwe stalsystemen en mestverwerking een deel van de geëxporteerde koolstof in mest, toch binnen Nederland kan worden toegepast. Deze vaste mest komt met name beschikbaar na mestscheiding en verdere verwerking en de vaste fractie na scheiding bij de bron. De huidige export en verwerking van kippenmest blijft bestaan, maar de export van (verwerkte) runder- en varkensmest wordt verlaagd, en de koolstof uit deze mest wordt dan binnen Nederland toegepast. Door gebrek aan data nemen we aan dat deze maatregel op 50\% van de huidige export van runder- en varkensmest kan worden toegepast. Op basis van NCM (2020) is de huidige mestexport op basis van fosfaat bepaald. Als dit wordt omgerekend via de koolstoffosfaatverhouding van de mest komt dit voor Nederland neer op 230.000 kton extra C die uit dierlijke mest naar de bodem wordt aangevoerd. Deze hoeveelheid is naar rato van de stikstofgift uit dierlijke mest over de gewassen verdeeld.

\subsubsection{Compost en bokashi}

Compost bestaat uit organisch materiaal dat door micro-organismen is omgezet tot een stabiel eindproduct (Elferink en Vlaar, 2010). Het gaat hier om organisch materiaal, zoals groenafval en gft (groente-, fruit- en tuinafval), dat gecomposteerd is. Door deze toevoeging van compost kan de bodemkwaliteit verbeteren en het organischestofgehalte worden verhoogd. Daarnaast is er een behoefte aan hergebruik van reststromen binnen de circulaire economie (Koopmans et al., 2018). Er zijn verschillende soorten compost, namelijk van dierlijke mest, plantaardig groencompost en gftcompost of een mengsel van bovengenoemde (Elferink en Vlaar, 2010).

Bokashi is het eindproduct van een fermentatieproces van restproducten, o.a. plantenresten van de landbouw, bermmaaisel en gft-afval (Olle, 2021). Bokashi lijkt veel op compost, het heeft ook een hoog organischestof- en nutriëntengehalte (Quiroz and Céspedes, 2019). Omdat er zoveel verschillende inputmaterialen gebruikt kunnen worden, is bokashi erg verschillend van kwaliteit (Quiroz and Céspedes, 2019). Zo heeft bokashi gemaakt van gft-afval bijvoorbeeld een hoger gehalte aan nutriënten dan bokashi gemaakt van bermmaaisel (Romkens et al., 2020). Omdat fermentatie een anaeroob proces is, is de afbraak van organische stof veel lager en blijft meer koolstof behouden in vergelijking met compost. De vraag is echter in hoeverre deze C stabiel is en na toepassing in de bodem ook bijdraagt aan C-vastlegging. Effecten van bokashi op de bodemkoolstofopslag in de bodem zijn, net zoals bij compost en dierlijk mest, pas op de langere termijn zichtbaar (Romkens et al., 
2020). Langetermijnexperimenten met bokashi zijn vooralsnog niet beschikbaar, daarom kan er nog geen uitspraak worden gedaan over de effecten van bokashi op $\mathrm{CO}_{2}$-vastlegging in de bodem.

Voor het doorrekenen van de C-vastlegging zijn we daarom uitgegaan van compost, maar dit zou in de toekomst ook bokashi kunnen zijn, aangezien het concurrerende verwerkingsprocessen zijn voor grotendeels dezelfde organische reststromen. In Nederland wordt ongeveer 1800 kton compost per jaar geproduceerd, waarvan 500 kton gft-compost is en 1300 kton groencompost. Van de gft-compost gaat ongeveer $75 \%$ naar de landbouw en van de groencompost ongeveer $50 \%$ (BVOR, 2017). Voor het doorrekenen van deze maatregel is aangenomen dat het aandeel compost dat naar de landbouw gaat, wordt verhoogd naar $82,5 \%$ voor gft-compost en naar $75 \%$ voor groencompost. Dit is een subjectieve aanname, aangezien er geen studie beschikbaar is met een kwantitatieve inschatting van de potentieel toekomstige compostproductie in Nederland. Voor het uiteindelijke mitigatie-effect van deze maatregel is het wel van belang dat het totale volume compost toeneemt en niet dat het een verschuiving van de composttoepassing betekent, bijv. van parken naar landbouw. Er is echter nog geen studie beschikbaar die voor Nederland in kaart heeft gebracht hoeveel extra compost geproduceerd kan worden. In het model gaan we ervan uit dat compost wordt toegepast op land dat gebruikt wordt voor akkerbouw en snijmais. In het model wordt rekening gehouden met de geldende bemestingsnormen; dit betekent dat extra compost resulteert in een kleine afname van de toediening van (varkens)drijfmest vanwege beperkingen in de fosfaatgebruiksnorm.

\subsection{Vanggewassen/groenbemesters}

Onder groenbemesters en vanggewassen vallen gewassen die worden gezaaid buiten het groeiseizoen. Groenbemesters hebben als hoofdfunctie de bemesting van de bodem wanneer de plant (in zijn geheel) in het na- of voorjaar wordt ondergeploegd (Blanco-Canqui et al., 2015). Vanggewassen worden op eenzelfde manier geteeld, maar dienen als hoofddoel om uitspoeling van nutriënten te voorkomen in het najaar (Thorup-Kristensen, 2001). Er zijn meerdere soorten groenbemesters die veel gebruikt worden in Nederland (Haagsma et al., 2019):

- Grasachtigen: Zoals Engels en Italiaans raaigras en Japanse Haver

- Vlinderbloemigen: zoals klaver en voederwikke

- Kruisbloemigen: zoals bladrammenas en gele mosterd

- Overigen: zoals afrikaantjes en facelia

- Mengsels: in het kader van de vergroeningsregeling van het GLB wordt het gebruik van mengsels gestimuleerd

De keuze van groenbemester hangt af van het perceel en is onder andere afhankelijk van de structuur, beschikbare nutriënten, aaltjes, erosie en ook van het klimaat (vorstgevoeligheid). Verder kunnen sommige groenbemesters, zoals klavers, beter vroeg in de zomer worden gezaaid om nog behoorlijke biomassa te verkrijgen. Andere groenbemesters kunnen nog tot augustus/begin september worden gezaaid. Wel geldt dat ook hier de biomassa bij late zaai flink afneemt.

Bij maisteelt is het - voor telers op zand en löss - verplicht om een vanggewas te telen. Vanaf 2019 is dit aan datums gebonden. Bij snijmais moet het vanggewas vóór 1 oktober gezaaid te zijn. Voor korrelmais, Corn Cob Mix (CCM) en maiskolvenschroot (MKS), suikermais of biologisch geteelde mais geldt 31 oktober als uiterlijke datum. Bij consumptie- of zetmeelaardappelteelt op zand en löss is het vanaf 2021 ook verplicht om een vanggewas te zaaien. Aardappeltelers moeten dan voor 16 september een groenbemester zaaien. Lukt dat vanwege een latere oogst niet, dan moet er uiterlijk 31 oktober een wintergraan als vanggewas gezaaid worden (Haagsma et al., 2019). In 2017 werden op 50\% van het akkerbouwareaal in Nederland groenbemesters geteeld. Daarvan worden bladrammenas, gele mosterd en Italiaans raaigras het meest geteeld. In Gelderland werd in 2017 op ongeveer 21.000 ha ( $27 \%$ van het totale bouwland areaal in Gelderland) een vanggewas geteeld (Figuur 6). 


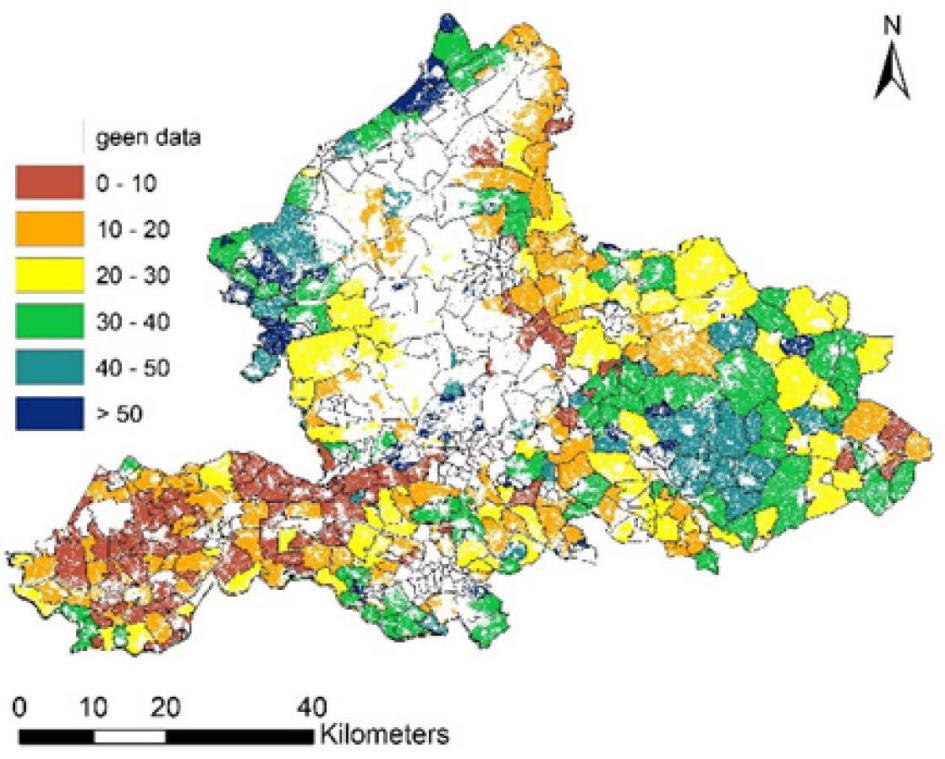

Figuur 6 Het gemiddelde areal met groenbemesters als percentage van het totale landbouwareaal in 2017.

De $\mathrm{CO}_{2}$ die vastgelegd kan worden, hangt af van de groenbemester en de zaaitijd. Hierbij geldt dat vroeger zaaien vaak (meer dan) twee keer zoveel biomassa oplevert en dus ook twee keer zoveel $\mathrm{CO}_{2}$ kan vastleggen. Bij deze maatregel is gekeken na welke gewassen een vanggewas/groenbemester kan worden toegepast en of dit een vroege of late zaaitijd zal zijn. Ook is rekening gehouden met de slagingskans van de groenbemester; bij suikerbieten bijvoorbeeld wordt een deel zo laat in het seizoen geoogst dat een groenbemester niet meer mogelijk is. Gebaseerd op een update van de kengetallen Effectieve Organische Stof die in Slim Landgebruik en PPS Beter Bodem Beheer zijn bepaald, is de gemiddelde C-input per groenbemester afgeleid. Aangezien er geen informatie bekend is over welk vanggewas na welke teelt wordt gebruikt, is uitgegaan van een gewogen gemiddelde van de huidige groenbemesters/vanggewassen. Dit resulteert in een gemiddelde C-aanvoer van $2900 \mathrm{~kg}$ $\mathrm{C} /$ ha voor een vroege groenbemester en $1100 \mathrm{~kg} \mathrm{C} /$ ha voor een late groenbemester.

\subsection{Gewasresten achterlaten}

Gewasresten van het hoofdgewas bestaan uit stengels, stoppels, bladeren en wortels. In sommige gevallen worden de gewasresten van het veld gehaald, om bijvoorbeeld te gebruiken als veevoeder, als stro in stallen of als bron voor bio-energie. Gewasresten die op het land achterblijven, dragen bij aan het verminderen van bodemerosie, verbeteren de bodemkwaliteit en -vruchtbaarheid, vormen een bron van nutriënten voor het opvolgende gewas en hebben een positief effect op waterinfiltratie en opslag (Paulsen et al., 2020; Cherubin et al., 2017). Daarnaast neemt het organischestofgehalte in bodems toe als gevolg van het achterlaten van gewasresten.

Momenteel worden vooral de gewasresten van graangewassen afgevoerd. Op basis van BIN is voor tarwe en gerst (belangrijkste graangewassen) bekend hoeveel er nu wordt afgevoerd (62 en $43 \%$ respectievelijk). Voor andere strogewassen is een aanname gemaakt: $25 \%$ afvoer voor stro van korrelmais en $50 \%$ voor de overige strogewassen (haver, rogge, koolzaad, triticale en overige granen). Voor het doorrekenen van de maatregel is de afvoer van stro op $0 \%$ gezet en blijven dus alle gewasresten op het land achter. In Gelderland wordt bijna 10.000 ha graangewassen verbouwd. 


\subsection{Snijmais met strokenfrees}

Bij deze maatregel wordt ervan uitgegaan dat snijmais in rotatie met tijdelijk grasland geteeld wordt in een rotatie van 3 jaar mais en 3 jaar gras. In plaats van gras te ploegen voor het inzaaien van de mais, wordt gebruikgemaakt van een strokenfrees, waardoor een deel van het gras blijft staan. Hierdoor blijven de aanvoer van koolstof uit de gewasresten van het gras deels behouden. In de langetermijnexperimenten van het programma Slim Landgebruik is een positief, maar niet significant effect gemeten voor het toepassen van deze maatregel (Koopmans et al., 2019). De C-aanvoer die deze maatregel kan leveren, wordt geschat op 2,1 ton C/ha. Dit is gebaseerd op de helft van Caanvoer van tijdelijk grasland $(0,5 * 3,4 \mathrm{t} \mathrm{C/ha})$, de $\mathrm{C}$-aanvoer van snijmais $(1,1 \mathrm{t} \mathrm{C} / \mathrm{ha})$ en een correctie voor huidige groenbemesters (geschat op ongeveer 0,7 ton $\mathrm{C} / \mathrm{ha}$ ). $\mathrm{Er}$ is aangenomen dat deze maatregel toepasbaar is op het gehele snijmaisareaal, wat voor Gelderland overeenkomt met 39.000 ha.

\subsection{Verhogen gewasproductie}

De gewasproductie kan potentieel verhoogd worden door betere rassen en/of de optimalisatie van irrigatie en bemesting en door vermindering van ziekteverwekkers. Een verhoogde gewasproductie resulteert over het algemeen ook in meer gewasresten en daarmee in een grotere aanvoer van organische stof naar de bodem en toename in bodem C-vastlegging. Op basis van historische trends in gewasopbrengst voor de belangrijkste gewassen is een inschatting gemaakt met welk percentage de gewasopbrengst nog verder kan stijgen. Een hogere gewasopbrengst wordt in het model automatisch doorgerekend naar een grotere aanvoer van C naar de bodem; zie voor details Lesschen et al. (in press). Uit deze analyse volgt dat er vooral winst te halen is bij (zaai)uien, zetmeelaardappelen, mais en suikerbieten. Aangezien dit vooral gewassen zijn waarbij een vaste aanvoer van organische stof wordt verondersteld, is het effect van deze maatregel echter wel beperkt.

\subsection{Akkerranden}

Akkerranden vallen onder functionele agrobiodiversiteit. Ze worden vooral aangelegd om de biodiversiteit in akkerland te verhogen. Het trekt met name bijen, hommels en andere bloembezoekers aan, maar ook allerlei zoogdieren. Bovendien kunnen akkerranden afvloeiing van sedimenten en nutriënten verminderen en gewasbescherming verbeteren (Bos et al., 2014). Daarnaast gaat het ook om de waardering voor de landbouw en eventuele recreatiemogelijkheden te verhogen. Om deze doelen te bereiken, worden er verschillende soorten akkerranden ingezaaid (Luske et al., 2015) waaronder bermmengsels (traag groeiende grassen), kruidenmengsels en combinaties van bergmengsels (20\%) en bloeiend kruidenmengsel (80\%).

Volgens Elbersen et al. (2018) wordt er nu voor 3\% van het landbouwareaal akkerranden toegepast, het gaat dan netto om een areaal van ongeveer 800 ha in Nederland. Voor het meetellen van akkerranden als onderdeel van de vergroening zijn regels opgesteld, zoals datum van inzaai, minimale periode, de gewassoorten die ingezaaid mogen worden (met name kruidachtingen, granen of gras) en de breedte en lengte van de strook. Verder mogen er geen meststoffen en gewasbeschermingsmiddelen gebruikt worden op de akkerrand. Voor het doorrekenen van deze maatregelen is aangenomen dat akkerranden op al het akkerbouw- en snijmaisareaal worden toegepast en gemiddeld $2 \%$ van dat areaal gaan beslaan. Informatie over de drogestofopbrengst van de akkerranden is maar zeer beperkt beschikbaar. Op basis van vergelijkbare gewassen is een organischestof-aanvoer uit plantenresten van 8 ton per ha akkerrand aangenomen. 


\section{$4.9 \quad$ Vogelakkers}

Vogelakkers worden aangelegd om de dichtheid van o.a. (veld)muizen in het agrarisch gebied te verhogen. Dit dient ten goede te komen aan (zeldzame) roofvogels. Een vogelakker is een volveldse, meerjarige maatregel die meestal voor 3 tot 4 jaar wordt aangelegd (Wiersma et al., 2019). In het veld worden stroken met een meerjarig groenvoedergewas (bijv. rode klaver op zandgrond, luzerne op kleigrond) afgewisseld met natuurbraakstroken. Dit zijn mengsels van grassen, granen en kruiden. De verdeling qua oppervlak is hierbij ongeveer $70 \%$ groenvoedergewas en $30 \%$ natuurbraak. De stroken met groenvoedergewas worden maximaal 3 à 4 keer per seizoen gemaaid en gebruikt als ruwvoer in de veehouderij (Wiersma et al., 2019). Door het drie- of zelfs vierjarige karakter van de vogelakker is het lastig inpasbaar op akkerbouwbedrijven met vooral eenjarige gewassen.

In het model is voor deze maatregel aangenomen dat $2 \%$ van het areaal intensieve akkerbouwgewassen (aardappelen, suikerbieten, bloembollen en uien) vervangen wordt door luzerne. Voor deze vogelakkers is de C-aanvoer van luzerne verhoogd met $1000 \mathrm{~kg} \mathrm{C} / \mathrm{ha}$, aangezien een deel van de vogelakker niet geoogst wordt en er dus meer biomassa voor de bodem overblijft.

\subsection{Niet-gemodelleerde maatregelen}

Onderstaande maatregelen zijn nog niet meegenomen in Roth-C, omdat de potentie voor Cvastlegging niet is bewezen of omdat er nog geen (of te weinig) data beschikbaar zijn over het effect van deze maatregelen op C-vastlegging in Nederlandse landbouwbodems. Deze maatregelen kunnen echter mogelijk wel nog bijdragen aan C-vastlegging in de bodem en voor twee maatregelen, agroforestry en landschapselementen, ook met name aan C-vastlegging in biomassa.

\subsubsection{Niet-kerende grondbewerking}

Niet-kerende grondbewerking is, in tegenstelling tot ploegen, een oppervlakkige bewerking van de bodem. Hierbij worden gewasresten alleen oppervlakkig met de bodem vermengd. Het toepassen van niet-kerende grondbewerking komt ten goede aan het bodemleven en de bodemstructuur, met als resultaat dat oppervlakteafvoer en erosie verminderen. Daarnaast zou niet-kerende grondbewerking ook bijdragen aan C-vastlegging door minder verstoring van de bodem. Eerdere studies lieten inderdaad vaak een toename van het C-gehalte in de bovengrond zien. Echter meer recente studies die naar het gehele bodemprofiel hebben gekeken, laten zien dat het C-gehalte in de bovengrond vaak toeneemt, maar in de ondergrond vaak afneemt (Haddaway et al., 2017). Het netto-effect op Cvastlegging is daardoor in eerdere studies overschat en voor Nederlandse condities waarschijnlijk niet of slechts beperkt aanwezig. Ook recente resultaten voor Nederland uit het Slim Landgebruik programma (Koopmans et al., 2019; Koopmans et al., 2020) laten geen eenduidig effect zien voor niet-kerende grondbewerking.

\subsubsection{Kruidenrijk grasland}

Kruidenrijk grasland voorziet in meerdere doelen. Het kan de biodiversiteit bevorderen en de populatie van weidevogels verbeteren. Ook bevat kruidenrijk grasland een betere basis voor de voeding van de koe (Geerts et al., 2014). Een kruidenrijk grasland is over het algemeen een combinatie van grassen, kruiden en vlinderbloemigen (Geerts et al., 2014). Het is te verwachten dat kruidenrijke graslanden, door de hogere biodiversiteit, een hogere drogestofopbrengst zal hebben. Dit omdat in een bio-divers grasland onder elke omstandigheid wel een soort goed kan produceren (Van Ruijven en Berendse, 2003) en omdat soorten elkaar aan kunnen vullen door complementariteit in nutriëntenopname (Van Ruijven en Berendse, 2005). Er loopt op dit moment een meerjarig experiment, waarbij gekeken wordt naar de effecten op C-vastlegging in de bodem, maar deze resultaten zijn nog niet beschikbaar. 


\subsubsection{Diep wortelende gewassen}

Wanneer er diep wortelende gewassen, zoals bepaalde grassen, worden geteeld, kunnen het grondwater en de beschikbare nutriënten (zoals N) beter worden benut (Van Eekeren et al., 2011). Naast het voorkomen van uitspoeling van nitraat kan diepere beworteling ook de bodemstructuur verbeteren en een rol spelen in de organischestof-opbouw (Van Eekeren et al., 2011). Uit recente studies is gebleken dat wortels een belangrijkere rol spelen t.o.v. bovengrondse biomassa met betrekking tot bodem C-opslag (Sokol et al., 2019). De studie van Rasse et al. (2005) liet zien dat wortels gemiddeld 2,4 keer zoveel C vastleggen ten opzichte van bovengrondse biomassa. Er zijn echter nog onvoldoende data beschikbaar om het effect op C-vastlegging goed vast te stellen en het RothC-model kan alleen worden gebruikt voor de kwantificering van C-vastlegging in de bovengrond.

\subsubsection{Agroforestry}

We spreken van agroforestry wanneer houtige, meerjarige gewassen zoals bomen en struiken bewust onderdeel uitmaken van de akkerbouw, groenteteelt en/of de veehouderij. Dit betekent dat houtige gewassen worden geteeld op hetzelfde perceel als waar de gewassen worden verbouwd en/of de weide wordt begraasd of gemaaid. De houtige gewassen kunnen voor meerdere doeleinden worden aangeplant, zoals de productie van fruit, noten of hout (Norén et al., 2019). Agroforestry kan op vele manieren worden toegepast. In Nederland kennen we een viertal vormen van agroforestry:

- Silvopastorale systemen waarbij een combinatie wordt gemaakt van productief grasland en vee met bomen of struiken;

- Rijenteeltsystemen waarbij een combinatie wordt gemaakt van akkerbouw, vollegrondsgroenteteelt of fruitproductie met bomen en struiken;

- Windhagen waarbij een haag wordt geplaatst bij grasland of bouwland om de wind te breken;

- Voedselbosbouw waarbij een teeltsysteem wordt gecreëerd dat bestaat uit verschillende vegetatielagen voor de productie van o.a. fruit, noten, groente en kruiden (Luske et al., 2020).

Er wordt aangenomen dat agroforestry-systemen kunnen bijdragen aan klimaatmitigatie, doordat koolstof wordt vastgelegd in het systeem. Koolstof wordt vastgelegd in de boombiomassa en in de bodem (Peichl et al., 2006). In het Masterplan Agroforestry dat in opdracht van het ministerie van LNV is opgesteld, staat het streven om in 203025.000 hectare landbouwgrond in te richten als agroforestry (Luske et al., 2020). Bij een realisatie van deze arealen agroforestry zal dat voor Nederland leiden tot een gemiddelde jaarlijkse vastlegging van ongeveer $90 \mathrm{kton} \mathrm{CO}_{2} / \mathrm{jaar}$ (Lesschen et al., in press). Er is geen verdere uitsplitsing naar provincies gemaakt, maar naar rato van landbouwareaal zou dat voor Gelderland ongeveer 10 kton $\mathrm{CO}_{2} /$ jaar zijn.

\subsubsection{Landschapselementen}

Landschapselementen zijn natuurlijke vegetaties in het landschap die van oudsher onder andere dienden als perceelscheiding, veekering of houtwinning. Echter, door de komst van prikkeldraad, de schaalvergroting en ruilverkaveling zijn vele hectaren landschapselementen verloren gegaan. Nederland kent verschillende typen landschapselementen, zoals houtwallen, elzensingels, bomenrijken, griendjes, struweelhagen en natuurvriendelijke oevers. Ze bepalen in sommige delen van Nederland de identiteit van een streek en de structuur van het landschap. Daarnaast vervullen landschapselementen verschillende ecosysteemdiensten en vertegenwoordigen ze een hoge natuurwaarde. De natuurlijke vegetatie zorgt ook voor een hoge C-voorraad, met name in de biomassa van struiken en bomen.

In Lesschen et al. (in press) is een eerste inschatting gemaakt van de mogelijke bijdrage aan $\mathrm{CO}_{2}$ vastlegging in landschapselementen op landbouwgronden. Hierbij is gebruikgemaakt van data over biomassa in landschapselementen van De Boer en Oosterbaan (2004). Figuur 7 laat het huidig aandeel landschapselementen binnen de landbouw in Gelderland zien. De vastlegging is berekend voor een scenario waarbij op $1 \%$ van het landbouwareaal landschapselementen worden toegepast en een scenario waarbij dit wordt vergroot naar $2 \%$. Het gaat hier respectievelijk om 0,7 en $1,7 \%$ omzetting van het landbouwbouwareaal in Gelderland naar landschapselementen. Door deze omzetting zou Gelderland bij het $1 \%$ scenario 45 kton $\mathrm{CO}_{2} /$ jaar in totaal extra vastleggen, en bij het $2 \%$-scenario 
106 kton $\mathrm{CO}_{2} /$ jaar. Hierbij is aangenomen dat deze vastlegging voor 15 jaar kan worden volgehouden. Daarna wordt een nieuw evenwicht bereikt tussen groei en oogst van de biomassa in landschapselementen.

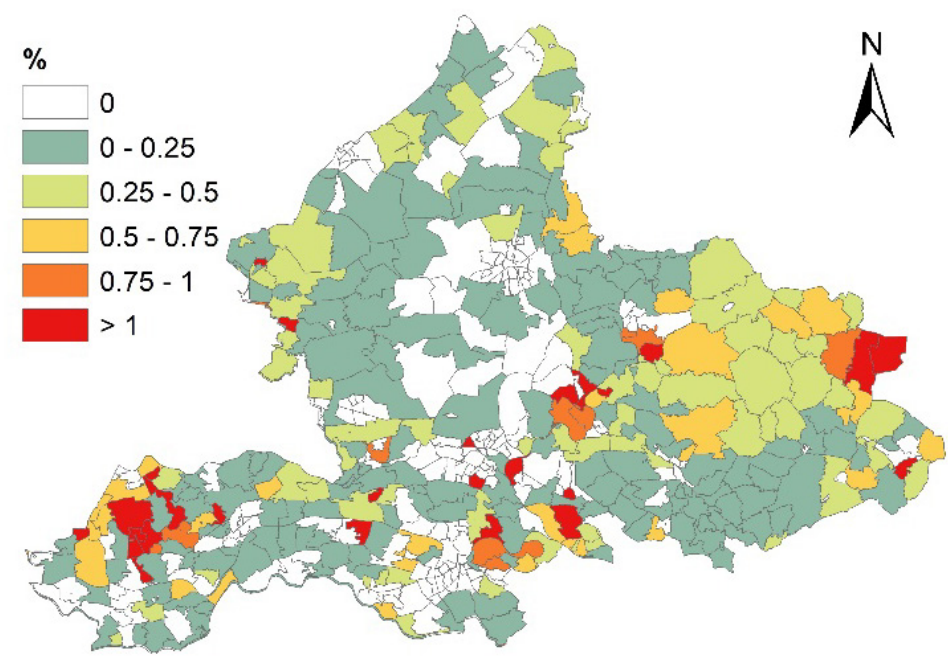

Figur $7 \quad$ Huidig aandeel landschapselementen als percentage van het totale landbouwareaal. 


\section{$5 \quad$ Resultaten en discussie}

\section{$5.1 \quad$ Huidige bodemkoolstofbalans}

Voor de berekening van de koolstofbalans, het verschil tussen de aanvoer en afbraak van koolstof in de bodem, is eerst de aanvoer van koolstof bepaald. De gemiddelde C-aanvoer op grasland is $6400 \mathrm{~kg}$ $\mathrm{C} /$ ha, terwijl dit voor akkerland een stuk lager is met $3600 \mathrm{~kg} \mathrm{C} /$ ha (Figuur 8). Het merendeel van de $\mathrm{C}$-aanvoer komt uit gewasresten, met name voor grasland, terwijl $\mathrm{C}$ uit dierlijke mest en compost een kleiner aandeel heeft. De afbreekbaarheid van de gewasresten is echter wel hoger vergeleken met dierlijke mest en compost.

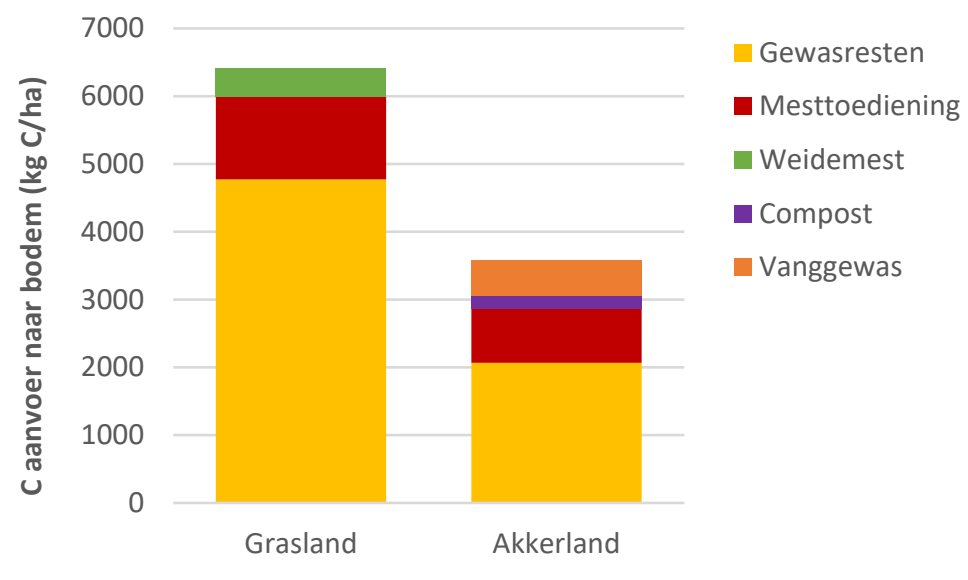

Figur 8 Gemiddelde C-aanvoer naar de bodem voor grasland en akkerland voor Gelderland.

Voor het jaar 2017 is een berekening gemaakt van de bodem C-balans voor de huidige situatie, de zogenaamde baseline. Het effect van de maatregelen wordt afgezet tegen deze baseline. De koolstofbalans laat een duidelijk verschil zien tussen grasland en akkerland (Figuur 9). Grasland heeft gemiddeld gezien een positieve koolstofbalans $(0,18 \mathrm{t} \mathrm{C/ha}$ onder zandgronden en $0,26 \mathrm{t} \mathrm{C/ha}$ onder kleigronden) en akkerland (incl. snijmais) een negatieve (-0,36 t C/ha onder zandgronden en $-0,12 \mathrm{t}$ $\mathrm{C} /$ ha onder kleigronden). Vooral in de gebieden rondom de Veluwe en in het oosten van Gelderland, op de armere zandgronden, is de koolstofbalans negatief. De gebieden met de positiefste koolstofbalans liggen rondom de rivieren op de kleigronden. De gemeten OS-gehalten zijn in die gebieden ook duidelijk hoger. Echter in Figuur 5 was voor die gebieden juist een kleine afname in het OS-gehalte onder grasland te zien tussen de periodes 2006-2010 en 2016-2020. Mogelijk is dit verschil te verklaren door de bodemdiepte, aangezien de metingen zijn gebaseerd op de bovenste $10 \mathrm{~cm}$ en de modelberekening voor de bovenste $25 \mathrm{~cm}$. 

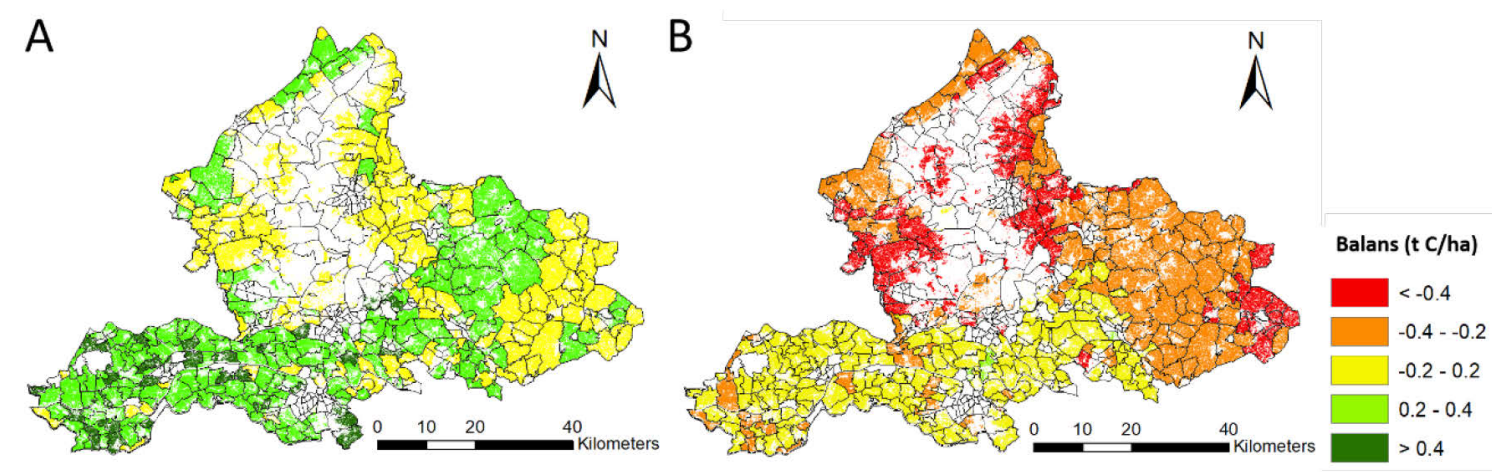

Figuur 9 Koolstofbalans (het verschil tussen de aanvoer en afbraak van koolstof in de bodem) van de baseline voor grasland $(A)$ en akkerland $(B)$, zoals berekend is met het RothC-model.

\subsection{Potentie C-vastleggingsmaatregelen}

Het effect van de maatregelen die C-vastlegging bevorderen, is weergegeven in Figuur 10. Voor Gelderland zijn meer blijvend grasland, extra vaste mest, snijmais met strokenfrees en vanggewassen /groenbemesters de maatregelen met de meeste potentie voor C-vastlegging. Dit zijn allemaal maatregelen die met name toepasbaar zijn in de melkveehouderij. Meer blijvend grasland kan door de omzetting van tijdelijk grasland en snijmais per jaar $27 \mathrm{kton} \mathrm{CO}_{2}$ extra vastleggen in de bodem. Toepassing van meer vaste mest zou kunnen leiden tot een extra $\mathrm{CO}_{2}$-vastlegging van 27 kton per jaar, door een toename van de C-aanvoer uit dierlijke mest met $12 \%$. Deze berekening voor vaste mest is echter uitgevoerd op landelijke schaal en de potentiële extra beschikbare hoeveelheid vaste mest is naar rato van de huidige mestaanvoer verdeeld. Dit betekent dat er relatief meer vaste mest naar grasland gaat, omdat de huidige dierlijke mestgift op grasland hoger is dan op akkerland. In de praktijk gaan deze nieuwe vaste mestproducten waarschijnlijk juist meer in de akkerbouw toegepast worden. Dat zou betekenen dat het effect van deze maatregel voor Gelderland mogelijk overschat wordt. Het areaal snijmais is in Gelderland relatief groot (ruim 38.000 ha in 2017), waardoor de maatregel snijmais met strokenfrees ook een behoorlijke potentie heeft met 16 kton $\mathrm{CO}_{2}$ per jaar. Het inzaaien van vanggewassen/groenbemesters na de oogst is een eenvoudige maatregel met een potentiële $\mathrm{CO}_{2}{ }^{-}$ vastlegging van 13 kton per jaar. In de gebieden waar nu al mais op zandgrond geteeld wordt, is het al verplicht om na de oogst een groenbemester te zaaien, maar met vroeger inzaaien kan de opbrengst van de groenbemester, en daarmee de C-aanvoer naar de bodem, nog wel worden verhoogd.

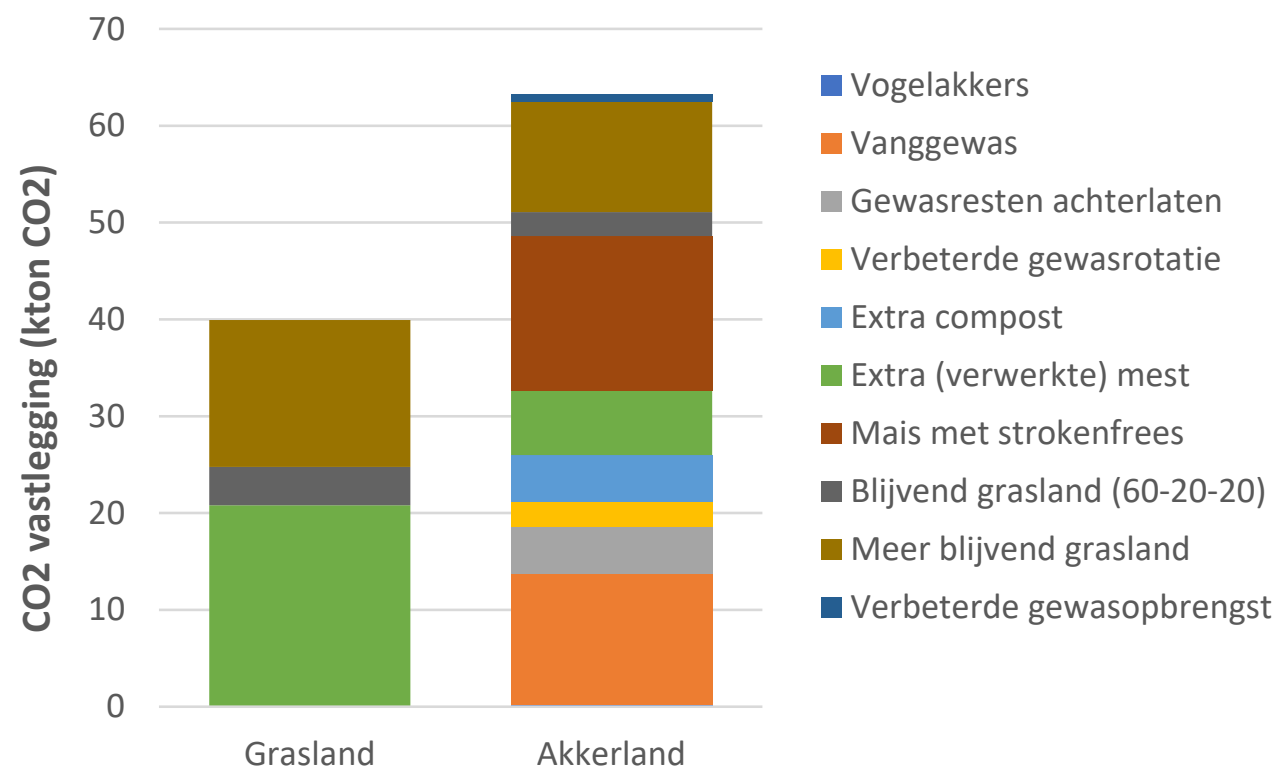

Figuur 10 De potentiële bijdrage die maatregelen kunnen leveren aan het verhogen van de $\mathrm{CO}_{2}$ vastlegging in Gelderse landbouwbodems. 
Het verbeteren van de gewasrotatie heeft in Gelderland maar een zeer beperkte bijdrage aan $\mathrm{CO}_{2}$ vastlegging. Dit komt omdat in Gelderland het areaal akkerbouw beperkt is en al een relatief groot aandeel rustgewassen (gem. ongeveer 50\%) in de gewasrotatie is opgenomen, waardoor er weinig ruimte is voor een groter aandeel hiervan. Gewasresten achterlaten, compost toedienen, het verhogen van de gewasproductie en vogelakkers hebben ook weinig potentie in Gelderland door het beperkte aandeel akkerbouw. De $\mathrm{CO}_{2}$-vastlegging die gerealiseerd kan worden door deze maatregelen wordt respectievelijk geschat op 5 kton $\mathrm{CO}_{2}, 5$ kton $\mathrm{CO}_{2}, 1$ kton $\mathrm{CO}_{2}$ en 0,2 kton $\mathrm{CO}_{2}$ per jaar. De maatregel akkerranden had zelfs een negatief effect op de koolstofvoorraad, omdat de akkerranden niet bemest worden en soms ook gewassen met een hogere aanvoer van organische stof vervangen. De maatregel is daarom niet opgenomen in de resultaten. Als de maatregel alleen zou worden toegepast bij intensieve gewassen met een lage OS-aanvoer, zoals aardappelen en uien, zou het wel een positief, maar klein effect hebben.

De meeste maatregelen kunnen in combinatie met elkaar worden toegepast, alleen de maatregel optimaal landgebruik (60-20-20-regel) en meer blijvend grasland overlappen. De doorrekening van alle maatregelen samen (excl. de 60-20-20-landgebruikmaatregel) levert een totale potentiële $\mathrm{CO}_{2}$ vastlegging op in Gelderland van 86 kton $\mathrm{CO}_{2}$ per jaar. Ten opzichte van de totale potentiële $\mathrm{CO}_{2}-$ vastlegging voor Nederland ( $900 \mathrm{kton} \mathrm{CO}_{2}$, Lesschen et al. (in press)) is dat voor het areaal minerale landbouwgronden in Gelderland relatief weinig, aangezien het areaal minerale landbouwgronden in Gelderland $15 \%$ van het totaal is.

Naast de totale $\mathrm{CO}_{2}$-vastleggingpotentie is het ook van belang om te weten hoeveel een maatregel gemiddeld per hectare kan vastleggen, zodat een boer een goede afweging kan maken welke maatregelen het effectiefst zijn voor zijn bedrijf. Tabel 2 geeft een overzicht van de $\mathrm{CO}_{2}$-vastlegging per hectare en voor welk areaal dit in Gelderland toepasbaar is. De maatregelen blijvend grasland (beide varianten), verbeterde gewasrotatie en vanggewas/groenbemester hebben allemaal een gemiddelde $\mathrm{CO}_{2}$-vastlegging van ongeveer 1 ton $\mathrm{CO}_{2} /$ ha/jaar. Vogelakkers zijn ook nog behoorlijk effectief $\left(0,8\right.$ ton $\left.\mathrm{CO}_{2} / \mathrm{ha} / \mathrm{jaar}\right)$, maar zijn maar op een heel beperkt areaal toepasbaar. Extra vaste mest en compost daarentegen zijn op een groot areaal toepasbaar, maar zijn maar beperkt beschikbaar en inzetbaar binnen de huidige mestwetgeving en hebben daardoor een lage $\mathrm{CO}_{2}-$ vastlegging per ha. In de praktijk zullen compost en vaste mest op specifieke percelen worden toegepast, waardoor de vastlegging per ha hoger zal zijn.

Tabel $2 \mathrm{CO}_{2}$-vastlegging per hectare, totale potentie en areaal waar de maatregel daadwerkelijk wordt toegepast.

\begin{tabular}{|c|c|c|c|}
\hline Maatregel & $\begin{array}{l}\text { Areaal } \\
1000 \text { ha }\end{array}$ & $\begin{array}{r}\text { Potentie } \\
\text { kton } \mathrm{CO}_{2} / \text { jaar }\end{array}$ & $\begin{array}{l}\mathrm{CO}_{2} \text {-vastlegging } \\
\mathrm{kg} \mathrm{CO}_{2} / \mathrm{ha} / \mathrm{jaar}\end{array}$ \\
\hline Extra (verwerkte) vaste mest & 224.3 & 27.4 & 120 \\
\hline Meer blijvend grasland & 25.5 & 26.6 & 1040 \\
\hline Mais met strokenfrees & 38.8 & 16.0 & 410 \\
\hline Vanggewas/groenbemester & 12.2 & 13.5 & 1110 \\
\hline $\begin{array}{l}\text { Blijvend grasland } \\
(60-20-20 \text { regel) }\end{array}$ & 6.1 & 6.4 & 1050 \\
\hline Gewasresten achterlaten & 9.6 & 5.0 & 520 \\
\hline Extra compost & 60.1 & 4.8 & 80 \\
\hline Verbeterde gewasrotatie & 2.4 & 2.6 & 1080 \\
\hline Verbeterde gewasopbrengst & 70.9 & 0.8 & 11 \\
\hline Vogelakkers & 0.2 & 0.2 & 810 \\
\hline Combinatie maatregelen & 224.3 & 86.4 & 390 \\
\hline
\end{tabular}

De potentiële $\mathrm{CO}_{2}$-vastlegging van de verschillende maatregelen is ook ruimtelijk in kaart gebracht. Figuur 11 laat voor elke maatregel zien wat de potentie is uitgedrukt in $\mathrm{kg} \mathrm{CO}_{2}$ per ha minerale landbouwgrond per jaar. Dit is een gecombineerde weergave van de effectiviteit en de toepasbaarheid van de maatregel. Meer blijvend grasland (B) heeft de hoogste potentie met name in het oosten van Gelderland. De maatregel meer vaste mest (D) heeft in heel Gelderland ongeveer dezelfde potentie. 
De potentie voor groenbemesters $(E)$ is redelijk variabel, maar het hoogst in de regio ArnhemNijmegen. De maatregel mais met strokenfrees $(G)$ en het invoeren van de 60-20-20-regel $(H)$ zijn alleen van toepassing op grondgebonden (melk)veehouderijen. Mais met strokenfrees kan in de gehele provincie tot een geringe toename in $\mathrm{CO}_{2}$-vastlegging leiden, terwijl de 60-20-20-regel (60\% blijvend grasland, $20 \%$ tijdelijk grasland in vruchtwisseling met $20 \%$ snijmais) het meeste effect heeft in de Achterhoek, waar het aandeel blijvend grasland nu dus veelal lager dan $60 \%$ is. De overige maatregelen hebben een beperkte potentie in Gelderland. Figuur 12 laat de potentiële vastlegging voor de combinatie van maatregelen zien. In de meeste regio's is een gemiddelde vastlegging van $400-600 \mathrm{~kg} \mathrm{CO} /$ ha landbouwgrond mogelijk. In het zuiden van de provincie is het potentieel iets hoger, terwijl rond de Veluwe en in het westen van de Betuwe de potentie lager ligt.

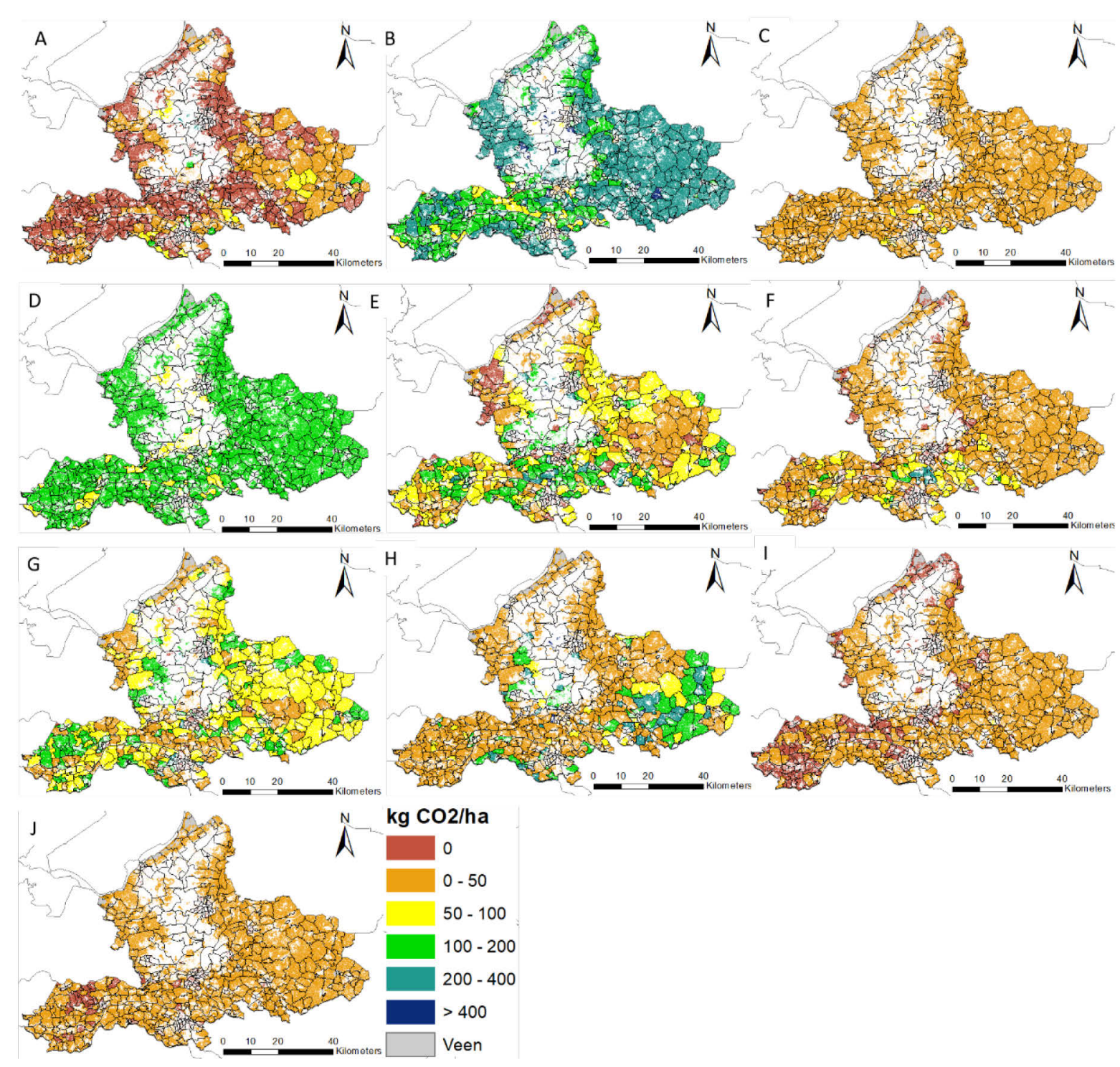

Figuur 11 Het effect van maatregelen die C-vastlegging bevorderen (in $\mathrm{kg} \mathrm{CO}_{2}$ per ha landbouwgrond) met A: verbeteren gewasrotatie, B: meer blijvend grasland, C: meer compost toedienen, D: meer vaste mest toedienen, E: vanggewas/groenbemester, F: gewasresten achterlaten, G: snijmais met strokenfrees, H: 60-20-20 landgebruik melkveehouderij, I: verhogen gewasproductie, J: vogelakkers. In alle kaartjes is dezelfde legenda gebruikt, waardoor de maatregelen makkelijk met elkaar vergeleken kunnen worden. 


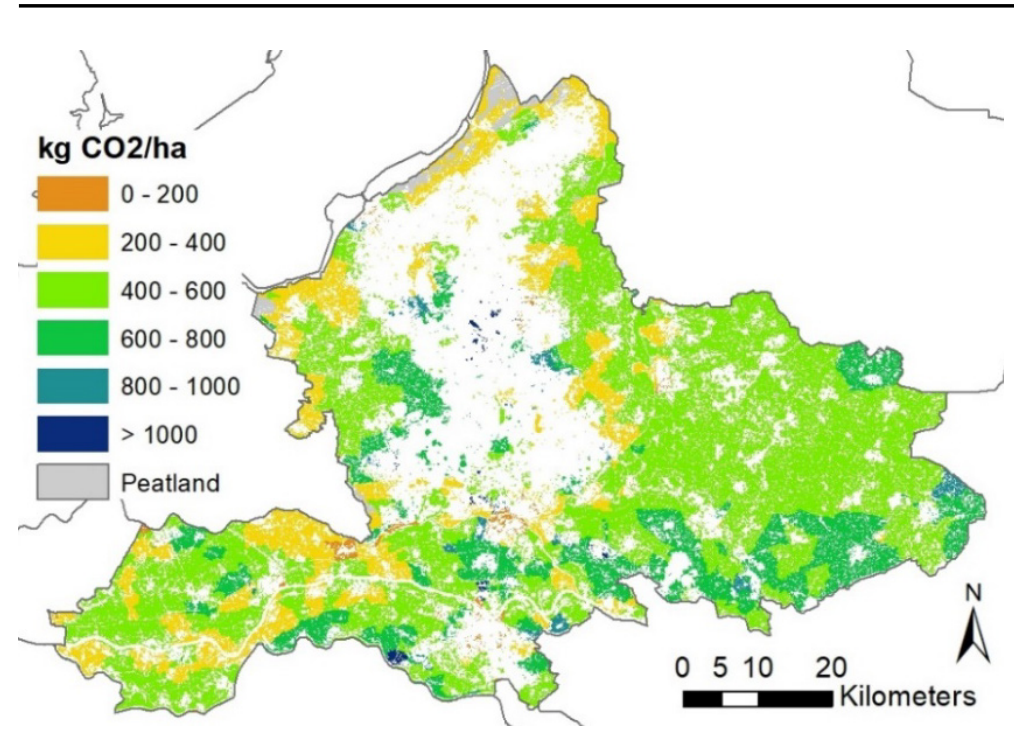

Figuur 12 Ruimtelijke verdeling van potentie voor $\mathrm{CO}_{2}$-vastlegging in Gelderse landbouwbodems voor de realistische combinatie van maatregelen.

\subsection{Discussie en aanbevelingen}

Potentie voor $\mathrm{CO}_{2}$-vastlegging

De berekende potentie voor $\mathrm{CO}_{2}$-vastlegging in Gelderse landbouwbodems is in totaal ongeveer 86 kton $\mathrm{CO}_{2}$ per jaar. De totale broeikasgasemissie uit de Gelderse landbouw (excl. glastuinbouw) was 3,2 Mton in 2016 (Jeurissen et al., 2019). In dat opzicht is een potentiële vastlegging van 86 kton, een kleine $3 \%$, niet heel veel. Maar zoals voor alle klimaatmitigatie maatregelen geldt, is er niet één maatregel met een heel grote potentie, en zal er dus breed op alle vlakken moeten worden ingezet. Mogelijk bieden ook kruidenrijk grasland en diep wortelende gewassen nog een additionele potentie, maar hiervoor ontbreken momenteel nog experimentele data om dit te kunnen kwantificeren. Naast $\mathrm{CO}_{2}$-vastlegging in bodems zijn er ook nog mogelijkheden voor $\mathrm{CO}_{2}$-vastlegging in biomassa. Binnen de landbouw zou dit kunnen in agroforestry-systemen en in landschapselementen. Als het areaal landschapselementen, zoals houtwallen, wordt uitgebreid naar 1 of $2 \%$ van het landbouwareaal, kan 45 tot $106 \mathrm{kton} \mathrm{CO}_{2} /$ jaar extra worden vastgelegd. Dit is in dezelfde ordegrootte als de potentie in bodems, maar bij landschapselementen gaat het wel deels ten koste van landbouwgrond.

Over het algemeen is het organischestofgehalte onder grasland een stuk hoger dan onder akkerland. De modelberekeningen laten zien dat graslanden over het algemeen een licht positieve organischestofbalans hebben, terwijl akkerlanden over het algemeen een licht negatieve trend laten zien (Figuur 9). Voor graslanden met een hoog organischestofgehalte is behoud van de organische stof de hoogste prioriteit; dit betekent het niet scheuren van dit blijvend grasland.

Drie maatregelen met de hoogste potentie voor additionele koolstofvastlegging in Gelderland zijn gericht op grondgebonden (melk)veehouderijen; blijvend grasland (meer blijvend grasland en 60-2020 optimaal landgebruik) en snijmais met strokenfrees. De hoogste potentie voor blijvend grasland ligt in het oosten van Gelderland (Figuur 11). De toepassing van extra vaste mest en/of compost wordt met name aanbevolen voor de akkerbouw- en snijmaispercelen. Deze maatregel is niet gebiedsgebonden, waardoor het voor heel Gelderland tot een hogere $\mathrm{CO}_{2}$-vastlegging kan leiden. Echter voor de bodem is het beter om deze externe organische stof uit vaste mest en compost meer gericht in te zetten op de gebieden waar de koolstofbalans nu negatief is en waar de OS-gehalten laag zijn. De negatiefste organischestofbalans is voor zandgronden rondom de Veluwe en in het oosten van Gelderland. Het wordt daarom aanbevolen om de focus op deze gebieden te leggen bij het implementeren van deze maatregel.

Initiatieven zoals de Groene Minerale Centrale van Groot Zevert Vergisting in de Achterhoek zijn voorbeelden van mestverwerking, waarbij varkensmest niet naar het buitenland wordt geëxporteerd, 
maar verwerkt in een stikstofkaliumconcentraat dat als kunstmestvervanger toegepast kan worden, een fosfaatmeststof (struviet) die geëxporteerd kan worden en een organische stof rijke

bodemverbeteraar, die door het lage P-gehalte wel nog binnen Nederland kan worden toegepast. De vraag blijft wel hoeveel bemestingsruimte er nog is voor dit soort producten en of boeren hier ook voor willen betalen.

\section{Duur van vastlegging}

In de berekeningen voor de potentiële $\mathrm{CO}_{2}$-vastlegging is uitgegaan van de bodem $\mathrm{C}$ balans voor één jaar. Een toename in het organischestofgehalte van de bodem kan echter niet eeuwig door blijven gaan, aangezien de bodem dan weer een nieuw evenwicht bereikt tussen aanvoer en afbraak van organische stof. Hoelang het duurt tot dit nieuwe evenwicht wordt bereikt, is niet direct te zeggen. Voor de emissieregistratie wordt voor veranderingen van de bodem C-voorraad vaak een standaardperiode van twintig jaar gebruikt, zoals ook aangegeven is in de IPCC-richtlijnen. Echter onder Nederlandse klimaatomstandigheden (koeler en vochtiger) zal deze periode langer zijn, omdat de processen van koolstofopbouw en afbraak langzamer verlopen. Schulp en Verburg (2009) lieten zien dat verschillen in historisch landgebruik na meer dan honderd jaar nog steeds een deel van de variatie in OS-gehalte konden verklaren, dus dat nog geen nieuw evenwicht was bereikt.

Resultaten van praktijkmetingen van het OS-gehalte onder grasland (De Wit et al., 2018; Iepema et al., 2021) laten zien dat na dertig tot veertig jaar een maximaal OS-gehalte wordt bereikt. Echter gaat het hier wel om bodemmonsters van de bovenste $10 \mathrm{~cm}$, mogelijk gaat de opbouw van de koolstofvoorraad nog wel langer door in de laag daaronder. Met een bodem C-model zoals RothC zou dit ook voor langere tijd doorgerekend kunnen worden, maar dat is voor deze studie niet gedaan. Concluderend kan gezegd worden dat de potentie voor C-vastlegging tijdelijk is, maar het kan naar verwachting zeker voor een periode van minimaal dertig jaar bijdragen aan klimaatmitigatie. Koolstofvastlegging in bodems moet dan ook gezien worden als een oplossing die tijd 'koopt' om ondertussen andere technieken te ontwikkelen die broeikasgasemissies moeten verminderen.

\section{Monitoring}

Voor het meten van het effect van veranderingen in bodembeheer op bodem $\mathrm{C}$ zijn metingen nodig over langere tijd, aangezien C-vastlegging een relatief langzaam proces is, waarbij het gaat om kleine verschillen t.o.v. van een grote bestaande voorraad. Daarnaast is er vaak een grote ruimtelijke variatie in organischestofgehalte, zelfs binnen een perceel, die samenhangt met o.a. kleine hoogteverschillen, verschillen in drainage en aanwezigheid van veenlagen.

De meeste bodem C-bevorderende maatregelen hebben een potentiële vastlegging van ruwweg 1-2 ton $\mathrm{CO}_{2}$ per ha per jaar. Dit betekent over tien jaar een toename van 2,7 tot 5,4 ton $\mathrm{C}$ per hectare, wat overeenkomt met een verhoging van het OS-gehalte met ongeveer 3 tot $6 \%$, uitgaande van een gemiddelde bodem met $5 \%$ organische stof. Dit zit in dezelfde ordegrootte als de foutmarge van de bodem OS-/C-metingen. Alleen als er over langere tijd wordt gemeten of als er veel meer bodemmonsters worden genomen kan er wel met meer zekerheid een verandering worden vastgesteld.

De laatste tijd zijn er verschillende nieuwe sensoren op de markt gekomen waarbij bodemeigenschappen ter plekke kunnen worden bepaald, op basis van near infrared (NIR) of mid infrared (MIR) technieken. In combinatie met precisielandbouw zouden deze sensoren ook op de tractor kunnen worden toegepast en daarmee de organischestofgehalten voor een perceel in kaart kunnen brengen. Aangezien het dan om vele metingen gaat, kan ook een nauwkeuriger gemiddeld OS-gehalte voor een perceel worden bepaald en daarmee ook voor monitoring geschikt maken. Hiervoor is echter nog wel verdere ontwikkeling nodig op het gebied van sensoren, toepassing bij grasland en vragen hoe moet worden omgegaan met wisselend vochtgehalte, verschillen in ploegdiepte en bodemstructuur en aanwezigheid van plantenresten.

\section{Afwenteling}

Het verhogen van het organischestofgehalte heeft in veel gevallen vaak ook een positief effect op andere bodem- en milieuaspecten, maar bepaalde maatregelen kunnen ook een negatief effect hebben. Er is een kwalitatieve inschatting gemaakt van de afwentelingseffecten voor de maatregelen 
die in deze studie zijn meegenomen. Afwenteling naar lachgasemissie, naar nitraatuitspoeling, bodemkwaliteit en bodembiodiversiteit zijn beoordeeld op basis van literatuur (o.a. Lesschen et al., 2012) en expertkennis vanuit het Slim Landgebruik programma (Tabel 3).

Tabel $3 \quad K$ walitatieve inschatting van mogelijke afwentelingseffecten van de gemodelleerde bodem C maatregelen (+ is positief milieueffect, - is negatief milieueffect).

\begin{tabular}{|c|c|c|c|c|}
\hline Maatregel & $\begin{array}{l}\text { Lachgas- } \\
\text { emissie }\end{array}$ & $\begin{array}{c}\text { Waterkwaliteit } \\
\text { ( } \mathrm{NO}_{3}-\text { uitspoeling) }\end{array}$ & Bodemkwaliteit & $\begin{array}{c}\text { Bodem- } \\
\text { biodiversiteit }\end{array}$ \\
\hline Meer blijvend grasland & + & + & + & + \\
\hline Mais met strokenfrees & + & + & + & $0 /+$ \\
\hline Vanggewas/ groenbemester & $-/+$ & + & + & + \\
\hline Extra compost & + & 0 & + & + \\
\hline Verbeterde gewasrotatie & + & + & + & + \\
\hline Gewasresten achterlaten & $-/+$ & $-/+$ & + & + \\
\hline Verbeterde gewasopbrengst & 0 & 0 & $0 /+$ & 0 \\
\hline
\end{tabular}

Het verhogen van het organischestofgehalte heeft ook effect op de stikstofkringloop en daarmee op de emissie van het broeikasgas lachgas $\left(\mathrm{N}_{2} \mathrm{O}\right)$. Lachgas wordt gevormd tijdens de microbiële processen in de bodem waarbij stikstof wordt omgezet (nitrificatie en denitrificatie). Aangezien lachgas een veel sterker broeikasgas is (298 keer sterker dan $\mathrm{CO}_{2}$ ), is het van belang dat deze emissie niet of maar zeer beperkt toeneemt. Het risico op lachgasemissie is groter voor de maatregelen die ook leiden tot extra aanvoer van stikstof, bijvoorbeeld bij extra vaste mest. Echter als de vaste mest met een hogere $\mathrm{CN}$-ratio de drijfmest met een lagere $\mathrm{CN}$-ratio vervangt, is het risico op lachgasemissie juist kleiner.

Voor waterkwaliteit is met name de uitspoeling van nitraat relevant. In principe kan meer organische stof ook meer nitraat binden en daarmee de uitspoeling verlagen. Echter net als voor lachgas kan bij bepaalde maatregelen de aanvoer van extra stikstof mogelijk tot een risico op extra nitraatuitspoeling leiden, bijvoorbeeld voor het achterlaten van gewasresten met een laag $\mathrm{CN}$-gehalte. De kwalitatieve analyse laat zien dat alle maatregelen in positieve zin bijdragen aan het verbeteren van de bodemkwaliteit in het algemeen (bodemstructuur, watervasthoudend vermogen, bodemvruchtbaarheid).

Extra organische stof bevordert ook het bodemleven en vaak ook de bodembiodiversiteit. De effecten op bodembiodiversiteit worden daarom ook ingeschat op positief of neutraal voor alle maatregelen. De gangbare opvatting was dat humus (de stabiele organische stof) in de bodem met name afkomstig is van afgebroken plantenresten. Maar recentelijk is duidelijk geworden dat een groot deel van de humus bestaat uit resten van (microbiële) bodemorganismen (necromass). Dit betekent dat de rol van het bodemleven een veel grotere rol heeft in de vorming van stabiele organische stof, met name in kleigronden waar het zogenaamde stabiele klei-humuscomplexen vormt. De precieze werking van de afbraakprocessen in de bodem is echter nog grotendeels onbekend, wat het ook lastig maakt om dit te vertalen in meer praktische adviezen hoe te sturen op beïnvloeding van het bodemleven (Hoffland et al., 2020). 


\section{Relevante projecten bodem C Gelderland}

Naast het huidige onderzoek lopen er meerdere andere projecten in de provincie Gelderland die ook aandacht besteden aan bodem C-vastlegging en/of onderzoek naar welke maatregelen de bodem positief beïnvloeden. In Tabel 4 is een kort overzicht gegeven van de relevante, huidige projecten. Een uitgebreidere samenvatting van elk project kan gevonden worden in Bijlage 1. Dit overzicht kan helpen bij het opstarten van nieuwe projecten en initiatieven die bodem C-vastlegging willen stimuleren. 


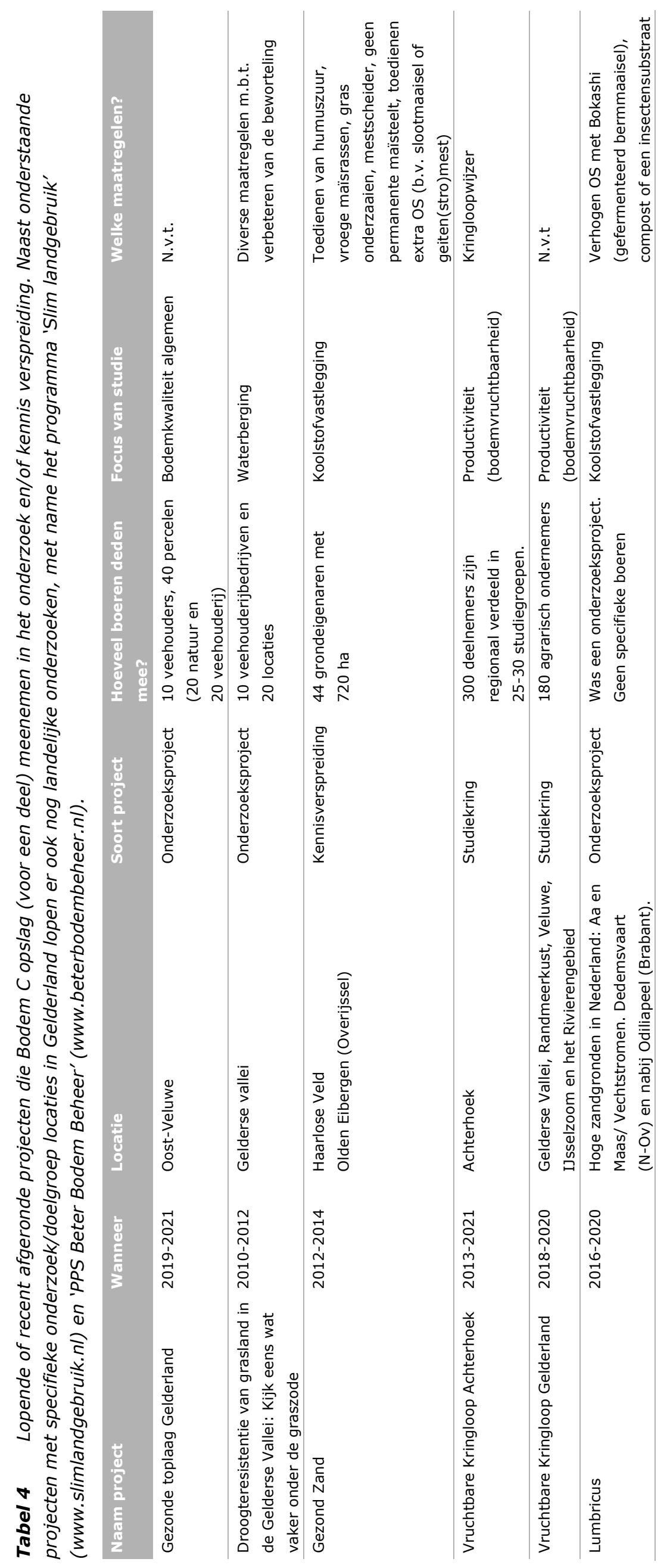

Wageningen Environmental Research Rapport 3097 | 33 


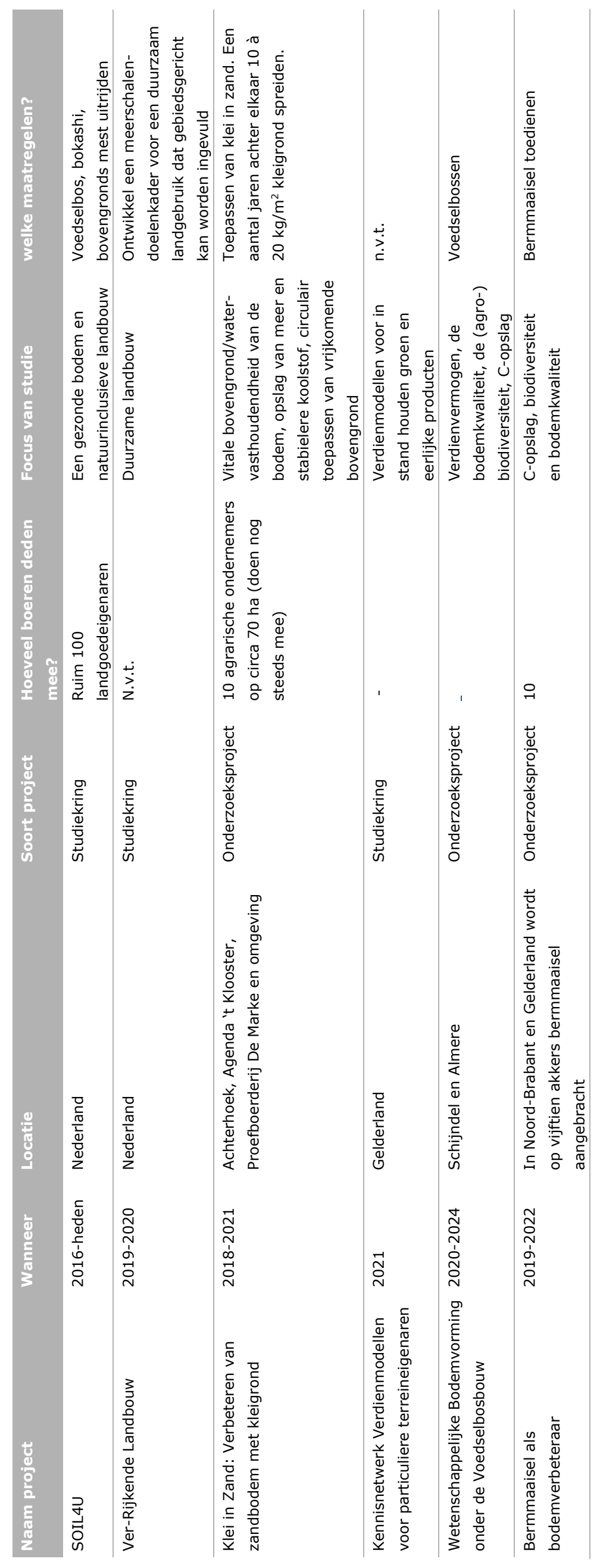

34 | Wageningen Environmental Research Rapport 3097 


\section{Literatuur}

Blanco-Canqui, H., Shaver, T.M., Lindquist, J.L., Shapiro, C.A., Elmore, R.W., Francis, C.A., Hergert, G.W., 2015. Cover crops and ecosystem services: Insights from studies in temperate soils. Agronomy Journal 107: 2449-2474.

Bos, M. M., \& Musters, C. J. M., 2014. De effectiviteit van akkerranden in het vervullen van maatschappelijke diensten. Een overzicht uit wetenschappelijke literatuur en praktijkervaring. Leiden, doctoral dissertation.

BRP, 2017. Basisregistratie Gewaspercelen (BRP). https://data.overheid.nl/dataset/ec09b995-aaf04c7f-8ee3-4a7ddf04bca5.

BVOR, 2017. Compost: effectieve organische stof in de bodem; marktcijfers 2016. BVOR.

Byrne, K., Kiely, G., 2009. Evaluation of Models (PaSim, RothC, CENTURY and DNDC) for Simulation of Grassland Carbon Cycling at Plot, Field and Regional Scale.

Cherubin, M. R., Oliveira, D. M. D. S., Feigl, B. J., Pimentel, L. G., Lisboa, I. P., Gmach, M. R., Varanda, L.L., Morais, M.C., Satiro, L.S., Popin, G.V., Paiva, S.R. de, Santos, A.K.B. dos, Vasconcelos, A.L.S. de, Melo, P.L.A. de, Cerri, C.E.P., Cerri, C. C., 2018. Crop residue harvest for bioenergy production and its implications on soil functioning and plant growth: A review. Scientia Agricola 75: 255-272.

Coleman, K., Jenkinson, D.S., 1996. RothC-26.3 - A model for the turnover of carbon in soil. In: Powlson, D.S., Smith, P., Smith, J.U. (eds). Evaluation of Soil Organic Matter Models. NATO ASI Series (Series I: Global Environmental Change) 38. Springer, Berlin, Heidelberg.

Coleman, K., Jenkinson, D.S., 2014. RothC - A model for the turnover of carbon in soil - Model description and users guide (Windows version). Updated June 2014. Rothamsted Research, Harpenden, UK.

Coleman, K., Jenkinson, D.S., Crocker, G.J., Grace, PR., Klír, J., Körschens, M., Poulton, P.R., Richter, D.D., 1997. Simulating trends in soil organic carbon in long-term experiments using RothC-26.3. Geoderma 81: 29-44.

Conijn, J.G., Lesschen, J.P., 2015. Soil organic matter in the Netherlands; Quantification of stocks and flows in the topsoil. Wageningen, Stichting Dienst Landbouwkundig Onderzoek. Research Institute Praktijkonderzoek Plant \& Omgeving/Plant Research International, Wageningen UR (University \& Research centre), PRI report 619/ Alterra report 2663.

De Boer, J., Oosterbaan, A., 2004. Op weg naar een duurzaam elzensingellandschap; Voorstudie naar haalbaarheid van verbreding van elzensingels. Alterra-rapport 1085. Alterra, Wageningen.

De Wit, J., Van de Goor, S., Pijlman, J., Van Eekeren, N.J.M., 2018. Opbouw organische stof met blijvend grasland. V-focus: 32-34.

De Wit, J., Van Eekeren, N., Honkoop, W., Pijlman, J., 2020. De waarde van vaste mest: Quick scan mest en natuur in de Krimpenerwaard. Rapport 2020-020 LbD. Louis Bolk Instituut, Bunnik.

Elbersen, B.S, Smidt, R., Van Doorn, A., 2018. Feiten en cijfers vergroening GLB 2017. Wageningen, Wageningen Environmental Research, Rapport 2907.

Elferink, E., Vlaar, L., 2010. Compost, Carbon en Credits; Een verkennende discussienota. CLM Onderzoek en Advies BV, CLM 720.

García-Condado, S., López-Lozano, R., Panarello, L., Cerrani, I., Nisini, L., Zucchini, A., Van der Velde, M., Baruth, B., 2019. Assessing lignocellulosic biomass production from crop residues in the European Union: Modelling, analysis of the current scenario and drivers of interannual variability. GCB Bioenergy 11: 809-831.

Geerts, R., Korevaar, H., Timmerman, A., 2014. Kruidenrijk grasland; Meerwaarde voor vee, bedrijf en weidevogels. Wageningen, Plant Research International.

Haagsma, W., Hoek, H., Molendijk, L., (2019) Handboek groenbemesters. https://www.handboekgroenbemesters. $\mathrm{nl} / \mathrm{nl} /$ handboekgroenbemesters.htm.

Haddaway, N. R., Hedlund, K., Jackson, L. E., Kätterer, T., Lugato, E., Thomsen, I. K., ... \& Isberg, P. E., 2017. How does tillage intensity affect soil organic carbon? A systematic review. Environmental Evidence, 6: 30. 
Hoffland, E., T. W. Kuyper, R. N. J. Comans and R. E. Creamer, 2020. Eco-functionality of organic matter in soils. Plant and Soil 455(1): 1-22.

Iepema, G., Hoekstra, N.J., de Goede, R., Bloem, J., Brussaard, L., van Eekeren, N. In press. Extending grassland age for climate change mitigation and adaptation on clay soils. European Journal of Soil Science.

Jeurissen, L., Voogd, J.C., Kros, H., Lesschen, J.P., 2019. Broeikasgasemissie van de Gelderse landen tuinbouw in 2016. Wageningen, Wageningen Environmental Research, Rapport 2947.

Koopmans, C., Bloem, J., 2018. Soil quality effects of compost and manure in arable cropping Results from using soil improvers for 17 years in the MAC trial. Louis Bolk Institute 2018-001 LbP.

Koopmans, C., Timmermans, B., Wagenaar, J.P., Van 't Hull, J., Hanegraaf, M., De Haan, J., 2019. Evaluatie van maatregelen voor het vastleggen van koolstof. Resultaten uit Lange Termijn Experimenten (LTE's). Louis Bolk Instituut.

Koopmans, C., B. Timmermans, J. de Haan, M. van Opheusden, I. Selin Noren, T. Slier en Jan Paul Wagenaar. 2020. Evaluatie van maatregelen voor het vastleggen van koolstof in minerale gronden 2019-2023: Voortgangsrapportage april 2020. https://www.slimlandgebruik.nl/sites/default/files/2021-04/evaluatie-van-maatregelen-20192020_def.pdf

Lesschen, J.P., Kuikman, P.J., Van den Wyngaert, I., 2009. Nulmeting emissie broeikasgassen Gelderse land- en tuinbouw. Wageningen, Alterra, Alterra-rapport 1891.

Lesschen, J.P., Staritsky, I. and Velthof, G.L. 2011. Verkenning grootschalige toepassing van mineralenconcentraten in Nederland; Effecten op nutriëntenstromen en emissies. Alterra-rapport 2247. Alterra, Wageningen.

Lesschen, J.P., H. Heesmans, J. Mol, A.M. van Doorn, E. Verkaik, I. van den Wyngaert, P.J. Kuikman, 2012. Mogelijkheden voor koolstofvastlegging in de Nederlandse landbouw en natuur. Alterrarapport 2396, Alterra, Wageningen.

Lesschen, J.P., Hendriks, C.M.J., van der Linden, A., Keuskamp, J., Keuper, D., Timmermans, B., Hanegraaf, M., Conijn, S., Slier, T., 2020. Ontwikkeling praktijktool voor bodem C. Wageningen, Wageningen Environmental Research rapport 2990.

Lesschen, J.P., Hendriks, C.M.J., Slier, T., Porre, R., Velthof, G., Rietra, R., in press. De potentie voor koolstofvastlegging in de Nederlandse landbouw. Wageningen, Wageningen Environmental Research.

Luske, B., Hospers-Brands, A. J. T. M., Janmaat, L., 2015. Aanleg en onderhoud van akkerranden: Onkruid de baas blijven. Louis Bolk Instituut.

Luske, B., M.W.P., Bestman, K. van Veluw, E. Prins MSc, P. Rombouts, 2020. Samenvatting Masterplan Agroforestry: Advies voor het realiseren van een schaalsprong van agroforestry in Nederland. Rapport 2020-018 LbD. Louis Bolk Instituut.

Nederlands Centrum Mestverwaarding (NCM), 2020. Landelijke rapportage en inventarisatie export en verwerking dierlijke mest 2020.

Norén, I. S., Keur, J., Vijn, M. P., Schoutsen, M. A., Cuperus, F., Slier, T., De Vries, W., Van Goor, W., Schrijver, R.A.M., 2019. Factsheet Agroforestry: Klimaatcompensatie met agroforestry, wat is mogelijk?; Handreiking voor agrarisch ondernemers die bomen willen planten op hun bedrijf. Wageningen, Wageningen Open Teelten.

Olle, M., 2021. Review: Bokashi technology as a promising technology for crop production in Europe. Journal of Horticultural Science and Biotechnology 96, 145-152.

Paulsen, H.M. (Ed). 2020. Inventory of techniques for carbon sequestration in agricultural soils. Interreg project Carbon Farming.

Peichl, M., Thevathasan, N. V., Gordon, A. M., Huss, J., \& Abohassan, R. A., 2006. Carbon sequestration potentials in temperate tree-based intercropping systems, southern Ontario, Canada. Agroforestry systems, 66: 243-257.

Quiroz, M., Céspedes, C., 2019. Bokashi as an Amendment and Source of Nitrogen in Sustainable Agricultural Systems: a Review. Journal of Soil Science and Plant Nutrition 19, 237-248.

Rasse, D.P., Rumpel, C., Dignac, M.-F., 2005. Is soil carbon mostly root carbon? Mechanisms for a specific stabilisation. Plant and Soil 269: 341-356.

Romkens, P.F.A.M., Rietra, R.P.J.J., Spijker, J.H., 2020. Aanzet kennisprogramma circulair terreinbeheer; Landbouwkundig relevante eigenschappen van maaisel, bokashi en compost. Wageningen Environmental Research Rapport 3006, 46. 
Schulp, C. J. E. and P. H. Verburg., 2009. Effect of land use history and site factors on spatial variation of soil organic carbon across a physiographic region. Agriculture, Ecosystems \& Environment 133(1-2): 86-97.

Smith, P., Smith, J.U., Powlson, D.S., McGill, W.B., Arah, J.R.M., Chertov, O.G., Coleman, K., Franko, U., Frolking, S., Jenkinson, D.S., Jensen, L.S., Kelly, R.H., Klein-Gunnewiek, H., Komarov, A.S., Li, C., Molina, J.A.E., Mueller, T., Parton, W.J., Thornley, J.H.M., Whitmore, A.P., 1997. A comparison of the performance of nine soil organic matter models using datasets from seven long-term experiments. Geoderma 81: 153-225.

Sokol, N.W., Kuebbing, S.E., Karlsen-Ayala, E., Bradford, M.A., 2019. Evidence for the primacy of living root inputs, not root or shoot litter, in forming soil organic carbon. New Phytologist 221:223246

Thorup-Kristensen, K., 2001. Are differences in root growth of nitrogen catch crops important for their ability to reduce soil nitrate-N content, and how can this be measured? Plant and Soil 230: 185-195.

Van Bruggen, C., M. Gosseling, 2019. Dierlijke mest en mineralen 1990-2018. Centraal Bureau voor de Statistiek, Den Haag/Heerlen.

Van Dijk, W., Spruijt, J., Runia, W., Van Geel, W., 2012. Verruiming vruchtwisseling in relatie tot mineralenbenutting, bodemkwaliteit en bedrijfseconomie op akkerbouwbedrijven. Wageningen, Stichting Dienst Landbouwkundig Onderzoek (DLO). PPO nr. 527.

Van Eekeren, N.J.M., Iepema, G., Domhof, B., 2016. Goud van Oud Grasland; Bodemkwaliteit onder jong en oud grasland op klei. Louis Bolk Instituut: https://edepot.wur.nl/375725.

Van Eekeren, N.J.M., Philipsen, A.P., Hanegraaf, M.C., 2007. Blijvend grasland of gras klaver in rotatie met snijmaïs. V-focus 24-25.

Van Tol-Leenders, D., Knotters, M., De Groot, W., Gerritsen, P., Reijneveld, A., Van Egmond, F., Wösten, H., Kuikman, P., 2019. Koolstofvoorraad in de bodem van Nederland (1998-2018): CCNL. Wageningen, Wageningen Environmental Research, Rapport 2974.

Van Eekeren, N., Deru, J., de Boer, H., Philipsen, B., 2011. Terug naar de graswortel. Een betere nutrientenbenutting door een intensievere en diepere beworteling. Louis Bolk Instituut.

Van Ruijven J., Berendse F., 2003. Positive effects of plant species diversity on productivity in the absence of legumes. Ecology letters 6: 170-175.

Van Ruijven J., Berendse F., 2005. Diversity-productivity relationships: Initial effects, long-term patterns, and underlying mechanisms. Proceedings of the National Academy of Sciences of the United States of America, 102: 695-700.

Wenum, J., de Haan, J., van Geel, W., van Dijk, W., van Valen, A., Postma, R., Brinks, H., Brolsma, K., Heestermans, S., Mager, A., de Jongh, E., 2013. Handboek bodem en bemesting. Commissie Bemesting Akkerbouw/Vollegrondsgroententeelt (CBAV).

Wiersma, P., Luske, B., Bos, J., Hakkert, J., Ottens, H.J., Postma, M., Klaassen, R., Timmermans, B., Zanen, M., 2019. Vogelakkers; Het effect op de biodiversiteit en de landbouwkundige inpasbaarheid. Louis Bolk Instituut. 


\section{Bijlage 1 Beschrijving projecten}

\begin{tabular}{ll} 
Naam project & Gezonde toplaag Gelderland \\
Opdrachtgever & LTO-Noord en provincie Gelderland \\
\hline Uitvoerder & Louis Bolk Instituut \\
\hline Wanneer & $2019-2021$ \\
\hline Locatie & Oost-Veluwe \\
\hline Soort project & onderzoeksproject \\
\hline Korte omschrijving project & Onderzoeksproject naar het effect van bodemleven, zoals \\
& springstaarten, mijten en schimmelgrazers op de \\
organischestofafbraak. Ook de rol van beweiding, maaien en pesticiden & is meegenomen. \\
\hline Hoeveel boeren deden mee? & $\begin{array}{l}10 \text { veehouders, } 40 \text { percelen (20 natuur en 20 veehouderij) gemeten } \\
\text { aan organischestofafbraak en organische stof. }\end{array}$ \\
\hline Focus van studie & Bodemkwaliteit algemeen \\
\hline Bodemtype & Zand \\
\hline Welke maatregelen? & $\begin{array}{l}\text { Er zijn geen maatregelen genomen. Er is gekeken naar factoren die } \\
\text { organischestofafbraak bepalen. Dit zijn de geschiedenis van bemesten, } \\
\text { de huidige landbouwpraktijk, de invloed van pesticiden. }\end{array}$ \\
\hline Succesfactoren voor toepassing maatregelen & Maaien en blijvend grasland werkt positief. \\
\hline Barrières voor toepassing maatregelen & Omzetten naar natuurgrond kan belemmerend werken. Aanwezige \\
\hline Monitoring? (algemeen en specifiek voor OS/OC) & OS en bodemleven \\
\hline Link naar website & Geen \\
\hline Referentie van gepubliceerd rapport (als & $\begin{array}{l}\text { Publicatie is in voorbereiding } \\
\text { beschikbaar) }\end{array}$ \\
\hline
\end{tabular}




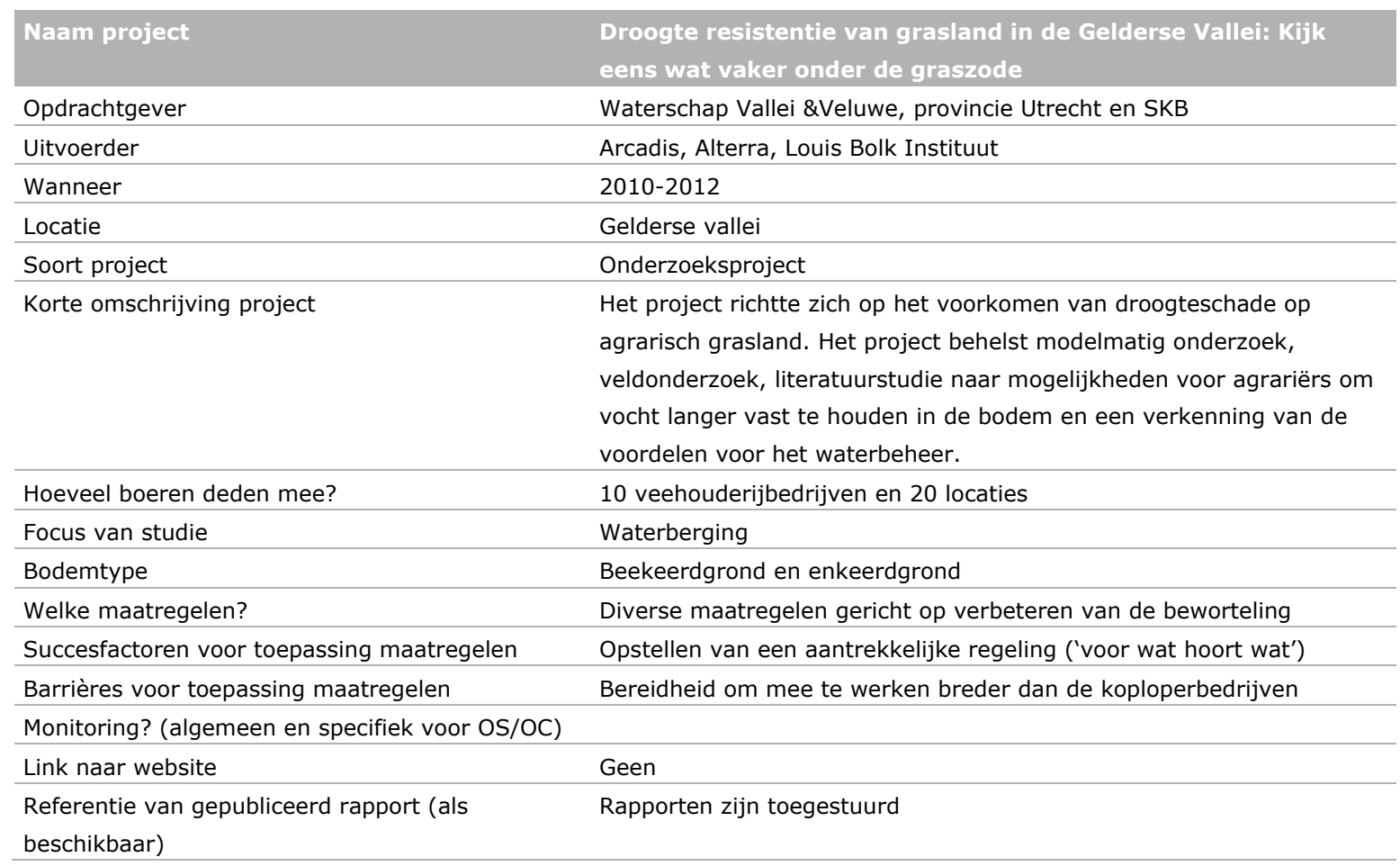


Naam project

Opdrachtgever

Wanneer

Locatie

Soort project

Korte omschrijving project

Hoeveel boeren deden mee?

Focus van studie

Bodemtype

Welke maatregelen?
Uitvoerder

Gezond Zand

Ministerie van Economische Zaken, Stichting Hoe Duurzaam, Vitens en Alterra Wageningen UR ROM3D

2012-2014

Haarlose Veld

Olden Eibergen (Overijssel)

kennisverspreiding

Deelname aan kennisbijeenkomsten, excursies of praktijkmiddagen.

En optioneel maatregelen ten gunste van de organischestof-

ontwikkeling.

44 grondeigenaren met 720 ha

Koolstofvastlegging

Beekeerd en veldpodzol

Toedienen van humuszuur, teelt van vroege maïsrassen, onderzaaien

van gras tussen de maïs, mestscheider om organische stof op

bedrijfsniveau beter te verdelen, anders omgaan met de

vruchtwisseling (geen permanente maïsteelt), het toedienen van extra

organische stof uit bv. slootmaaisel of geiten(stro)mest. Alle

deelnemende boeren hebben organischestofgehalten verzameld en

doorgegeven.

Succesfactoren voor toepassing maatregelen

Goede kennisdeling

Barrières voor toepassing maatregelen

Er is een lange adem nodig, praktijk is weerbarstig. Verhuur van grond

is een risico op achteruitgang van de bodem

Monitoring? (algemeen en specifiek voor OS/OC)

Link naar website

http://hoeduurzaam.nl/nieuw-project-1/

Referentie van gepubliceerd rapport (als

Brochure toegestuurd

beschikbaar) 


\begin{tabular}{|c|c|}
\hline Naam project & Vruchtbare Kringloop Achterhoek \\
\hline Opdrachtgever & Waterschap Rijn en IJssel, Rabobank For Farmers, Vitens \\
\hline Uitvoerder & Agrariërs hebben eigen bestuur \\
\hline Locatie & Achterhoek \\
\hline Soort project & Studiekring \\
\hline Focus van studie & Productiviteit (bodemvruchtbaarheid) \\
\hline Bodemtype & Divers zand \\
\hline Welke maatregelen? & Kringloopwijzer \\
\hline Succesfactoren voor toepassing maatregelen & $\begin{array}{l}\text { Boeren leren van elkaar. Integrale aanpak, kijken naar de hele } \\
\text { kringloop. }\end{array}$ \\
\hline Barrières voor toepassing maatregelen & $\begin{array}{l}\text { Financiering is lastig. Bovenwettelijke maatregelen gaat ten koste van } \\
\text { de productiviteit. Er wordt nog gekeken naar verdienmodel. }\end{array}$ \\
\hline \multicolumn{2}{|l|}{ Monitoring? (algemeen en specifiek voor OS/OC) } \\
\hline Link naar website & https://vruchtbarekringloopachterhoek.nl/ \\
\hline
\end{tabular}




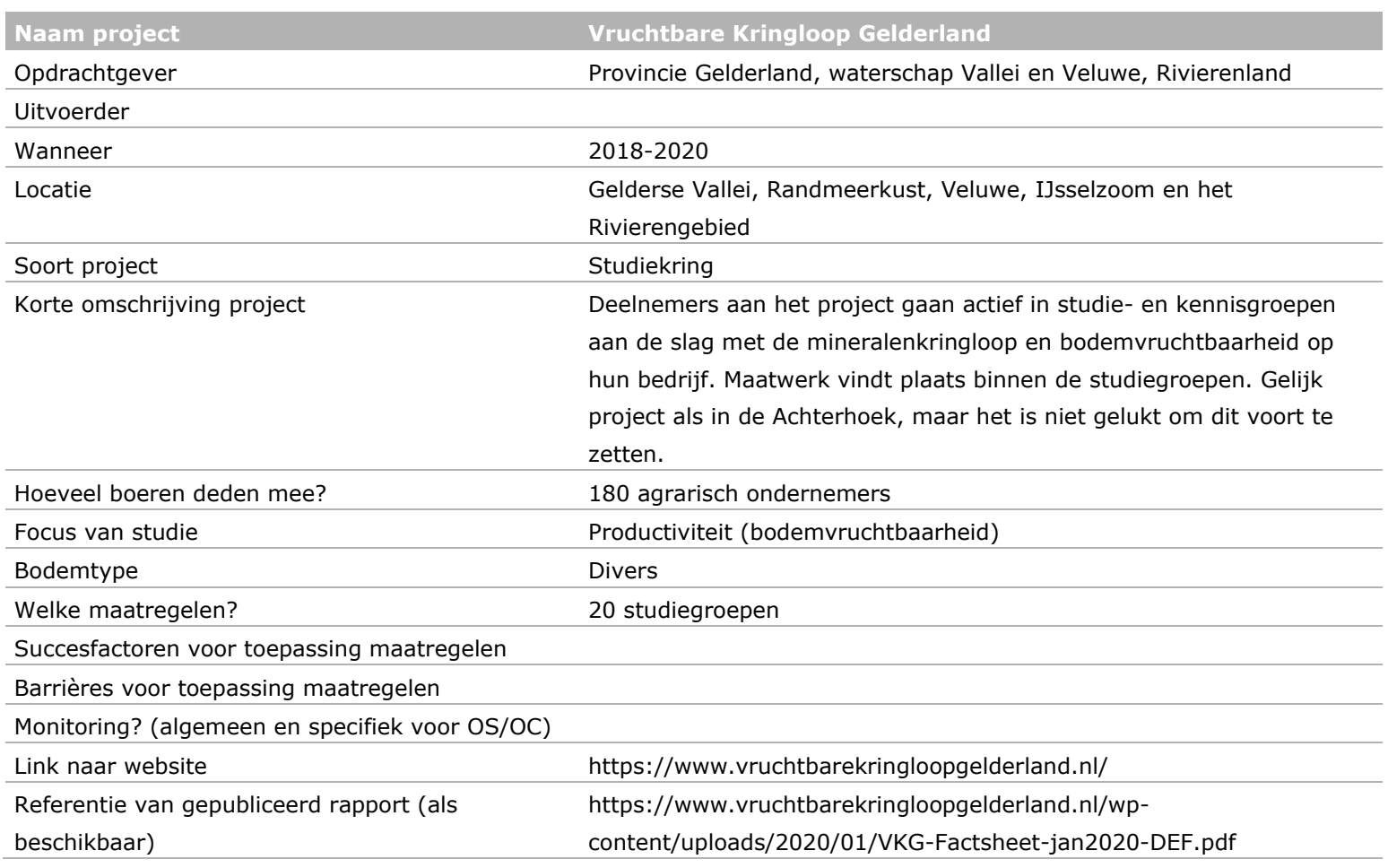




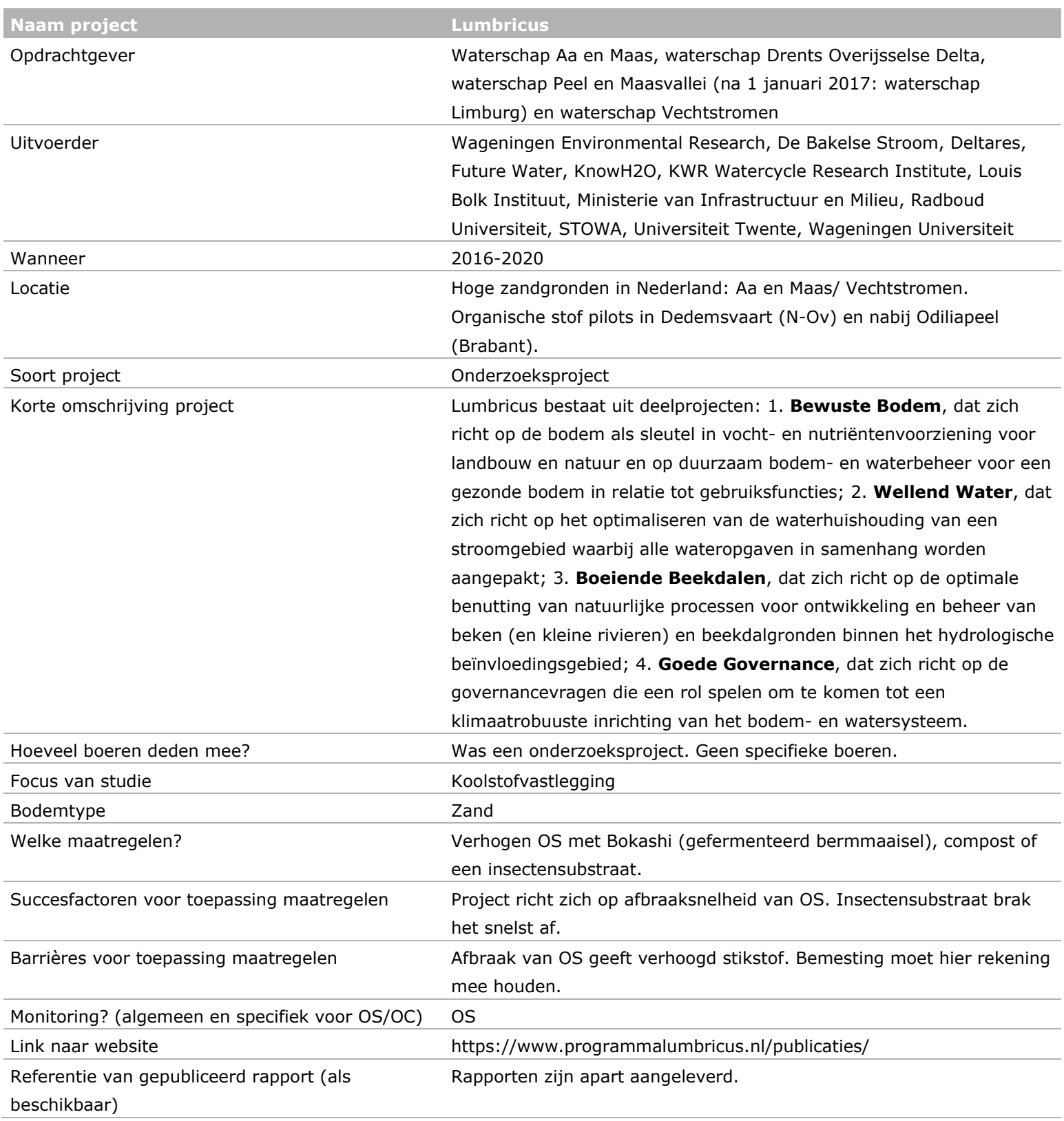


Soil4U is een praktijkplatform van en voor particuliere landgoederen, nauw verbonden aan de Federatie Particulier Grondbezit. Een breed scala aan organisaties, professionals en geïnteresseerde burgers neemt deel aan dit platform.

Uitvoerder Samenwerkingsverband van de landgoederen Vilsteren, Bingerden en Grootstalruim. Inmiddels ruim 100 landgoedeigenaren die samen goed zijn voor 120.000 van de in totaal 200.000 ha particulier grondbezit.

Wanneer

Soort project

Korte omschrijving project

\section{6-heden}

Nederland

Studiekring

Soil4U is een platform dat vanuit de praktijk kennis en inspiratie biedt voor landgoederen die een transitie beogen naar een gezonde bodem en bedrijfsvoering. Drie particuliere landgoederen in Nederland gaan op een innovatieve manier de uitdaging aan samen met boeren, ondernemers en consumenten. Om te laten zien dat een transitie naar natuurinclusieve landbouw mogelijk is, met inbegrip van alle partners.

Hoeveel boeren deden mee? Ruim 100 landgoedeigenaren

Focus van studie Een gezonde bodem en bedrijfsvoering en natuurinclusieve landbouw.

Bodemtype Meerdere

Welke maatregelen? voedselbos, bokashi, bovengronds mest uitrijden

Succesfactoren voor toepassing maatregelen

Barrières voor toepassing maatregelen

Monitoring? (algemeen en specifiek voor OS/OC)

N.v.t.

Link naar website https://www.soil4u.nl/

Referentie van gepubliceerd rapport (als

beschikbaar) 

RiBuilT

\begin{tabular}{|c|c|}
\hline Uitvoerder & \\
\hline Wanneer & $2019-2020$ \\
\hline Locatie & Nederland \\
\hline Soort project & Studiekring \\
\hline Korte omschrijving project & $\begin{array}{l}\text { Het Programma Ver-rijkende Landbouw is het startpunt om een } \\
\text { nieuw/aangepast landbouwsysteem te introduceren. Een systeem dat } \\
\text { ten opzichte van het huidige systeem een positief effect heeft op } \\
\text { bodemgebruik en in het verlengde daarvan op de bodemkwaliteit. }\end{array}$ \\
\hline Hoeveel boeren deden mee? & N.v.t. \\
\hline Focus van studie & $\begin{array}{l}\text { volhoudbare, duurzame en grondgebonden landbouw, die op een niet } \\
\text { uitputtende en niet vervuilende manier uitwisselt met het bodem en } \\
\text { watersysteem: } \\
\text { - Waterhuishouding en zuivering } \\
\text { - Koolstofvastlegging } \\
\text { - (Bodem)biodiversiteit } \\
\text { - Mineralenkringlopen } \\
\text { - Voedsel/biomassa productie } \\
\text { - Landschap }\end{array}$ \\
\hline Bodemtype & Meerdere \\
\hline Welke maatregelen? & $\begin{array}{l}\text { Ontwikkel een meerschalen-doelenkader voor een duurzaam } \\
\text { landgebruik dat gebiedsgericht kan worden ingevuld. }\end{array}$ \\
\hline Succesfactoren voor toepassing maatregelen & N.v.t \\
\hline Barrières voor toepassing maatregelen & N.v.t. \\
\hline Monitoring? (algemeen en specifiek voor OS/OC) & N.v.t. \\
\hline Link naar website & https://verrijkendelandbouw.nl/ \\
\hline $\begin{array}{l}\text { Referentie van gepubliceerd rapport (als } \\
\text { beschikbaar) }\end{array}$ & $\begin{array}{l}\text { Schipper, L., Sloot, P., Zijlstra, R., Bruin, L., 2021, Verrijkende } \\
\text { landbouw - Een meerschalen-benadering }\end{array}$ \\
\hline
\end{tabular}




\begin{tabular}{|c|c|}
\hline Naam project & Klei in Zand: Verbeteren van zandbodem met kleigrond \\
\hline Opdrachtgever & $\begin{array}{l}\text { Provincie Gelderland, Royal HaskoningDHV en Proefboerderij De Marke } \\
\text { van Wageningen UR }\end{array}$ \\
\hline Wanneer & $\begin{array}{l}\text { Eerste veld is aangelegd in } 2018 . \text { WUR onderzoek 2019-2021. } \\
\text { Praktijkonderzoek 2020-heden. }\end{array}$ \\
\hline Locatie & Achterhoek, Agenda 't Klooster, Proefboerderij De Marke en omgeving \\
\hline Soort project & Onderzoeksproject \\
\hline Korte omschrijving project & $\begin{array}{l}\text { Bij aanleg van nieuwe natuur en bij weg- en woningbouwrealisatie } \\
\text { komt goede klei/land - bouwgrond vrij. Deze kleigrond biedt } \\
\text { mogelijkheden om schrale zandgronden te verbeteren en de toplaag te } \\
\text { verdikken. }\end{array}$ \\
\hline Hoeveel boeren deden mee? & 10 agrarische ondernemers op circa 70 ha (doen nog steeds mee). \\
\hline Focus van studie & $\begin{array}{l}\text { Vitale bovengrond /vochthoudendheid van de bodem, opslag van meer } \\
\text { en stabielere koolstof, circulair toepassen van vrijkomende } \\
\text { bovengrond. }\end{array}$ \\
\hline Bodemtype & Zandbodem met laag percentage lutum. \\
\hline Welke maatregelen? & $\begin{array}{l}\text { Toepassen van Klei in Zand. Een aantal jaren achter elkaar } 10 \text { à } \\
20 \mathrm{~kg} / \mathrm{m}^{2} \text { kleigrond spreiden. }\end{array}$ \\
\hline Succesfactoren voor toepassing maatregelen & $\begin{array}{l}\text { Logisch boerenverstand, historisch perspectief, verwacht snel resultaat } \\
\text { van het effect op de vochtvasthoudendheid. }\end{array}$ \\
\hline Link naar website & Edepot.wur.nl/471955 \\
\hline $\begin{array}{l}\text { Referentie van gepubliceerd rapport (als } \\
\text { beschikbaar) }\end{array}$ & N.v.t. \\
\hline
\end{tabular}




\begin{tabular}{|c|c|}
\hline Naam project & $\begin{array}{l}\text { Kennisnetwerk Verdienmodellen voor particuliere } \\
\text { terreineigenaren }\end{array}$ \\
\hline Opdrachtgever & Gelders Particulier Grondbezit (GPG) en provincie Gelderland \\
\hline Wanneer & 2021 \\
\hline Locatie & Gelderland \\
\hline Korte omschrijving project & Kennisontwikkeling, 3 pilots \\
\hline \multicolumn{2}{|l|}{ Hoeveel boeren deden mee? } \\
\hline \multicolumn{2}{|l|}{ Focus van studie } \\
\hline Bodemtype & Meerdere \\
\hline Monitoring? (algemeen en specifiek voor OS/OC) & Nee \\
\hline Link naar website & $\begin{array}{l}\text { https://www.grondbezit.nl/gpg-nieuwsbericht/gpg-kennisnetwerk- } \\
\text { verdienmodellen-van-start.html }\end{array}$ \\
\hline $\begin{array}{l}\text { Referentie van gepubliceerd rapport (als } \\
\text { beschikbaar) }\end{array}$ & n.v.t. \\
\hline
\end{tabular}



voor Ecologie (NIOO-KNAW), Stichting Voedselbosbouw Nederland, Aeres hogeschool, HAS Den Bosch

Wanneer 2020-2024

Locatie Praktijkonderzoek: Schijndel en Almere

Soort project

Korte omschrijving project
Tot op heden is er weinig wetenschappelijk onderzoek uitgevoerd naar de impacts van voedselbossen in gematigde klimaatzones. Om de (potentiële) meerwaarde van deze innovatieve, agrarische productiesystemen te toetsen en te onderbouwen, geven tien consortiumpartners de komende vier jaar uitvoering aan het onderzoeksproject Wetenschappelijke Bodemvorming onder de Voedselbosbouw. Doel van het project is om wetenschappelijk verantwoorde inzichten te genereren in de duurzaamheidsimpacts van voedselbossen in termen van verdienvermogen, klimaatmitigatie, (agro-)biodiversiteit, bodemkwaliteit en ecologische veerkracht.

Hoeveel boeren deden mee?

Focus van studie

Bodemtype

Welke maatregelen?

Succesfactoren voor toepassing maatregelen

Barrières voor toepassing maatregelen

Monitoring? (algemeen en specifiek voor OS/OC)

Link naar website

https://www.voedselbosbouw.org/single-post/wetenschappelijke-

bodemvorming-onder-de-voedselbosbouw

https://www.greendealvoedselbossen.nl/

Referentie van gepubliceerd rapport (als

beschikbaar) 
Provincie Noord Brabant en Gelderland, Waterschap de Dommel, Aa en Maas, en Brabantse delta en gemeente Sint Anthonis

Uitvoerder

\section{Wanneer}

Locatie

Soort project

Korte omschrijving project
Maartje van der Sloot, PhD, PEN, WUR

2019-2022

In Noord-Brabant en Gelderland wordt op vijftien akkers bermmaaisel aangebracht.

Onderzoeksproject

Gebruik van het bermmaaisel als bodemverbeteraar op de akkers zou een duurzame oplossing voor akker en berm kunnen betekenen met lage kosten voor de boer. Echter is er nog weinig bekend over de gedetailleerde reacties in de bodem en gewas na opbrengen bermmaaisel op lange termijn. Deze toepassing moet daarom nog grondig in realistische situaties worden onderzocht.

Hoeveel boeren deden mee? 10

Focus van studie

Bodemtype

Meerdere

Welke maatregelen? Bermmaaisel toedienen

Succesfactoren voor toepassing maatregelen Barrières voor toepassing maatregelen Zwerfafval tussen bermmaaisel

Monitoring? (algemeen en specifiek voor OS/OC) SOM

Link naar website

Referentie van gepubliceerd rapport (als

Nog niet beschikbaar

beschikbaar) 
Wageningen Environmental Research Postbus 47

6700 AA Wageningen

T 0317480700

www.wur.nl/environmental-research

Wageningen Environmental Research Rapport 3097

ISSN 1566-7197
De missie van Wageningen University \& Research is 'To explore the potential of nature to improve the quality of life'. Binnen Wageningen University \& Research bundelen Wageningen University en gespecialiseerde onderzoeksinstituten van Stichting Wageningen Research hun krachten om bij te dragen aan de oplossing van belangrijke vragen in het domein van gezonde voeding en leefomgeving. Met ongeveer 30 vestigingen, 6.800 medewerkers ( $6.000 \mathrm{fte}$ ) en 12.900 studenten behoort Wageningen University \& Research wereldwijd tot de aansprekende kennisinstellingen binnen haar domein. De integrale benadering van de vraagstukken en de samenwerking tussen verschillende disciplines vormen het hart van de unieke Wageningen aanpak. 


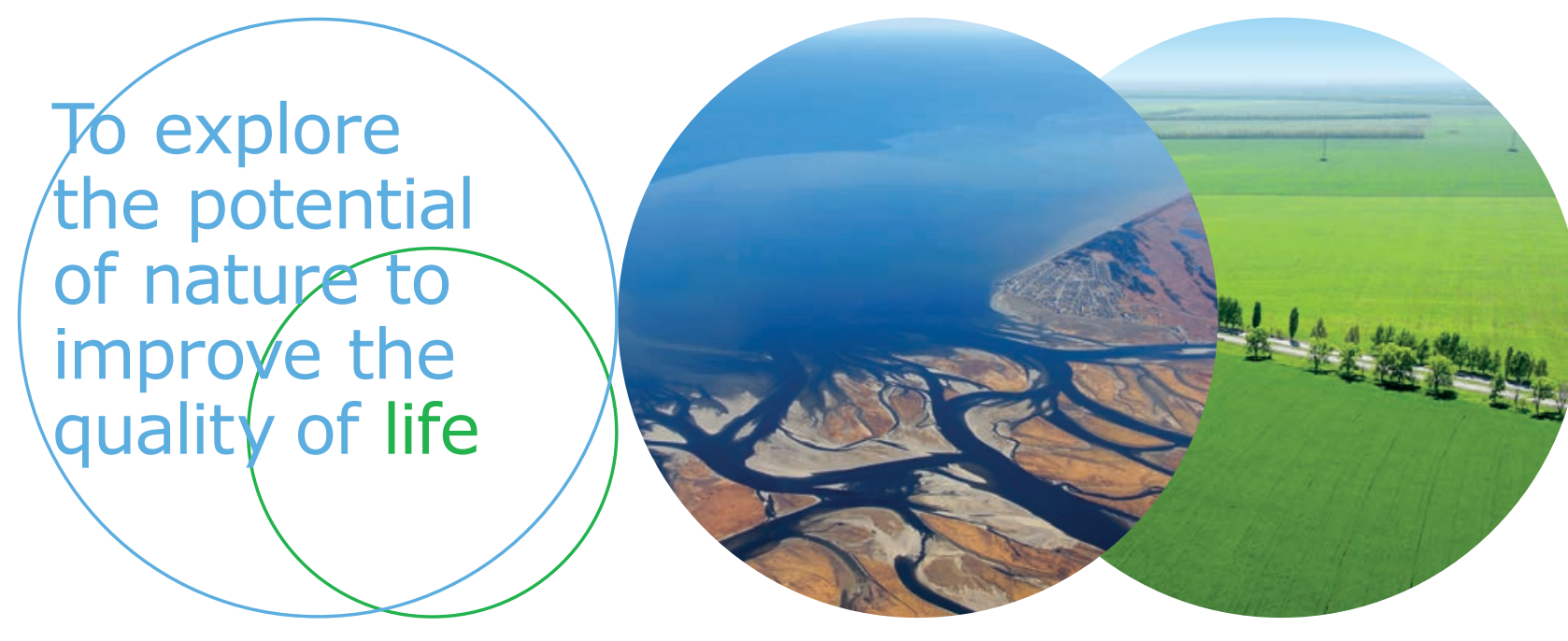

Wageningen Environmental Research Postbus 47

$6700 \mathrm{AB}$ Wageningen

T 317480700

www.wur.nl/environmental-research

Rapport 3097

ISSN 1566-7197
De missie van Wageningen University \& Research is 'To explore the potential of nature to improve the quality of life'. Binnen Wageningen University \& Research bundelen Wageningen University en gespecialiseerde onderzoeksinstituten van Stichting Wageningen Research hun krachten om bij te dragen aan de oplossing van belangrijke vragen in het domein van gezonde voeding en leefomgeving. Met ongeveer 30 vestigingen, 6.800 medewerkers (6.000 fte) en 12.900 studenten behoort Wageningen University \& Research wereldwijd tot de aansprekende kennisinstellingen binnen haar domein. De integrale benadering van de vraagstukken en de samenwerking tussen verschillende disciplines vormen het hart van de unieke Wageningen aanpak. 